\title{
A Global Perspective on Railway Inefficiency and the Rise of State Ownership, 1880-1912
}

\author{
Dan Bogart ${ }^{1}$ \\ Department of Economics UC Irvine \\ 3151 Social Science Plaza A \\ Irvine CA 92697-5100 \\ dbogart@uci.edu
}

\begin{abstract}
The rise of state ownership was one of the most significant policy changes in the railway sector in the early twentieth century. This paper estimates the cost inefficiency of railway sectors using stochastic frontier models and examines whether the rise of state ownership affected inefficiency. The results show that the trends in inefficiency differed substantially across countries from the 1880s to 1912. They also show that inefficiency increased with greater nationalizations and decreased with greater state railway construction. A counterfactual analysis suggests that the rise of state ownership contributed to lower inefficiency in most countries, but the effects within countries varied depended on whether state ownership increased through nationalizations or new construction.
\end{abstract}

Keywords: Railways; State Ownership; Cost Inefficiency; Stochastic Frontier Estimation;

Globalization

JEL Classifications: N40, N70, L92, P52

\footnotetext{
${ }^{1}$ I would like to thank participants at the International Transport Economics Conference at the University of Minnesota and seminar participants at UC Davis, Kyoto University, UCLA, IMT Lucca, Warwick University, and LSE for comments on earlier versions of this paper. I would also like to thank Jan-Luiten Van Zanden, David Good, Michael Mesch, Max-Stephan Schulze, Roman Studer, Petra Gerlach, Steve Nafziger, Giovanni Federico, and Ola Grytten for providing invaluable help in locating data. Finally I would like to thank Quan Trinh, Sarah Chiu, and Cecilia Lanata Briones for valuable research assistance.
} 


\section{Introduction}

Economic historians often analyze railways through their contribution to social savings. Contemporaries in the early twentieth century also discussed the developmental effects of railways, but with equal interest they analyzed the performance of railways as a sector. In 1910 railway revenues equaled around 6\% of GDP in countries like Britain and Germany. ${ }^{2}$ Railway tracks, locomotives, and stations also constituted a relatively large share of the total capital stock. According to estimates in the 1880 s, railways accounted for around $9 \%$ of total wealth in countries like Britain and Germany (Mulhall 1892, p. 589). Given the large size of the railway sector and its potential spillover effects on other sectors in the economy, any excess in operating costs could have substantial implications.

Railway operating expenses differed greatly across countries from the 1880 s to 1913 in part because the scale of outputs (i.e. ton miles and passenger miles), the density of services, and the price of inputs were all substantially different. However, even after accounting for these factors, there remain differences in operating expenses both across countries and within countries. Inefficiency is one reason why expenses differed. In general, inefficiency arises when firms or organizations do not minimize costs with respect to a given output level, input price vector, and available technology. In the railway context inefficiency would be associated with the failure to adopt more energy-efficient locomotives, poor network design, or the lack of coordination across railway lines. Inefficiency would also be associated with the misallocation of inputs, such as the failure to reduce the use of labor when wages increased relative to fuel or capital prices. Environmental factors like geography are another explanation for residual differences in expenses. Variation in elevation or rainfall could contribute to differences in

\footnotetext{
${ }^{2}$ The GDP figures are taken from Mitchell (1992). The sources for revenue will be discussed in the data section.
} 
expenses because railways traversed the landscape of a country. Distinguishing between inefficiency and environmental factors is important because there was scope for lowering inefficiency through the actions of policy makers, railway managers, and workers.

This paper addresses two questions. How did railway inefficiency differ across countries from the 1880s to 1912? How did the rise of state ownership influence railway inefficiency across countries and over time? The rise of state ownership marked one of the major policy shifts in the railway sector from the 1870s to 1913. Private ownership and operation was predominant in most countries in 1870. Afterwards there was an evolution towards greater state ownership and operation through greater construction of state-owned railways and nationalizations of privately-owned railways. By 1910 approximately $10 \%$ of the world's railway miles had been nationalized and 22\% were constructed by the state.

Today private ownership is generally believed to be more efficient than state ownership because it encourages competition and arguably provides stronger incentives for investment and innovation. ${ }^{3}$ However, it is not obvious that private ownership contributed to efficiency in the railway context c.1900. Contemporaries hotly debated the benefits and costs. ${ }^{4}$ Some echoed modern complaints about government ownership arguing that state railways lacked commercial discipline. Others took a different view and stressed that private railway companies were often guaranteed interest or dividends and thus had less incentive to cut costs. It was also noted that private companies had difficulties coordinating services and the adoption of technologies.

Inefficiency is estimated in this paper using stochastic frontier models and cross-country data on railway performance. The cross-country data are drawn from a number of sources like

\footnotetext{
${ }^{3}$ See Shleifer (1998) for summary of recent views on the efficacy of private ownership.

${ }^{4}$ For a sample of works see Edwards (1907), Cunningham (1906), Raper (1912), and Dunn (1913).
} 
the Statistical Abstract of Foreign Countries, published by the British Board of Trade. It includes total expenses, railway miles, passenger-miles, ton-miles, and construction costs for railways in 18 of the largest economies. Additional sources were used to combine the railway data with information on fuel prices and wages in these same economies. The stochastic frontier methodology involves the estimation of a cost function with the addition of a random term measuring inefficiency. ${ }^{5}$ Following other studies, the specification of the cost function includes variables for scale, density, input prices, and country fixed effects.

The results show that the average level of inefficiency was 0.058 , implying the average country could have reduced its annual costs by 5.8\% if it eliminated all inefficiency. More significantly the estimates suggest that the trends in inefficiency differed substantially across countries. The US, Belgium, France, and the Netherlands had the most efficient railway sectors by the 1900s, while Canada and Italy had the least efficient. In the 1890s the ranking of inefficiencies was quite different. Italy, Sweden, Austria, and Switzerland had the most efficient railway sectors, while the US and the Netherlands had the least efficient.

The effects of state ownership are analyzed using regressions of inefficiency on variables for the degree of nationalizations and state railway construction. The results show that inefficiency increased with nationalizations and decreased with greater state (as opposed to private) railway construction. These findings imply that the effects of state ownership differed depending on whether nationalizations or new state construction were more common. The results also provide estimates on the effects of greater state ownership in the most important railway countries by 1910. A counterfactual analysis shows that average inefficiency would have been $12 \%$ lower had there been no nationalizations in any country before 1910. On the other hand

\footnotetext{
${ }^{5}$ For an introduction to stochastic frontier models see Kumbhaker and Lovell (2000).
} 
inefficiency would have been $39 \%$ higher if no countries had more than $25 \%$ of their networks constructed by the state. These results suggest that the railway sector would have been more inefficient overall had there been less state ownership.

This paper contributes to the historical literature on railway efficiency and productivity. It builds on the studies by Crafts, Mills, and Mulatu (2007), Crafts, Leunig, and Mulatu (2008), Leunig (2006), Arnold and McCartney (2005), and Herranz-Loncan (2006), which estimate freight charges, fares, travel speeds, rates of return, productivity, and inefficiency for British and Spanish railways before 1912. It also builds on the work of Foreman-Peck (1987) and Bogart (2009) who analyze construction costs, nationalizations, and network development in a crosscountry setting. ${ }^{6}$

The paper also offers a new perspective on the role of policy choices in the global economy from 1870 to 1913 . In this period there was greater government intervention through increased spending on social services and infrastructure. ${ }^{7}$ Railways provide an important case to evaluate the effects of greater government intervention. The results reject the claim that private companies were always better than the state in managing railways. If that were the case, greater nationalizations and greater state railway construction should have contributed to inefficiency. Instead the results suggest that by the 1890s and 1900s greater private railway construction contributed to worse management of railways. A likely reason is that interest or dividend guarantees dulled the incentives for private railways to cut costs.

\footnotetext{
${ }^{6}$ The paper also relates to the contemporary literature on efficiency estimation. A number of studies have analyzed efficiency at the network or country-level and examined its relationship with ownership or regulatory policies. Some examples include Parisio (1999), Christopoulos, Loizides, and Tsionas (2001), and Cantos and Maudos (2001).

${ }^{7}$ See Lindert (2004) and Millward (2004) for studies of social spending and infrastructure.
} 
The estimates also suggest that state railway bureaucracies were becoming increasingly sophisticated. As one example, the Government of India organized railway conferences promoting better coordination and management of the rail network (Bell 1894). It also created the State Railway Provident fund which contributed one-half of one percent of state railway earnings to its employees in proportion to their salary and position. It appears some governments addressed the incentive problems highlighted by their critics at the turn of the century and today.

Lastly, the results suggest that nationalizations were associated with increases in inefficiency. One explanation is that the private companies that remained after nationalizations stopped maintaining their track or exerted less effort in monitoring employees because they anticipated future nationalizations. The transfer from private to governmental control might have also changed operating procedures and hindered efficiency especially in the short-term.

The paper is organized as follows. Section 2 introduces the data. Section 3 displays some basic patterns in the data. Section 4 discusses the methodology for estimating inefficiency. Section 5 reports the inefficiency estimates by country and decade. Section 6 analyses the connection between inefficiency and state ownership. Section 7 concludes.

\section{Data}

\subsection{Railway Performance}

Contemporaries collected a substantial amount of data on the financial performance of railways. Almost every aspect was measured including construction costs, operating expenses, revenues, and outputs. The British Board of Trade published summary data on railways in Britain, foreign countries, and British colonies annually starting in the 1870s. The main Board of 
Trade publications are the Statistical Abstract for the United Kingdom, the Statistical Abstract for the Principal and Other Foreign Countries, and the Statistical Abstract for the Several Colonial and other Possessions of the United Kingdom. These volumes marked one of the first attempts to compile and present comparable cross-national data. The information is clearly presented and is easily entered into spreadsheets for statistical analysis. ${ }^{8}$

The main variables are total railway miles, passengers transported, tons shipped, total expenses, and construction costs. Railway miles measure the total length of the network. Passengers transported and tons shipped partly characterize outputs, but they do not incorporate the distance of the trip or the haul. In some cases the Statistical Abstracts report the average haul and the average trip, which along with the data on passengers and tons shipped can be used to calculate passenger miles and ton miles. ${ }^{9}$ In other cases, International Historical Statistics and secondary sources provide data on ton miles and passenger miles. The appendix provides full details on the sources used in each country.

Total expenses measure the operational costs of railways. The data in the Statistical Abstracts do not distinguish between different types of expenses, so it is not possible to calculate cost shares. Other data sources show that expenses include the wage bill for train staff and station staff, spending on fuel, spending on maintenance to the track, plant, and equipment, and purchases of new capital goods like locomotives. ${ }^{10}$ The Statistical Abstracts do not report total expenses for Britain, Australia, India, and Canada; instead they report working expenses, which

\footnotetext{
${ }^{8}$ The statistical Abstracts are now available through web-based versions of the Parliamentary papers. See www. parlipapers.chadwyck.com for details.

${ }^{9}$ Passenger miles are calculated by multiplying the number of passengers transported by the average trip in miles; ton miles are calculated by multiplying tons shipped by the average haul in miles.

${ }^{10}$ See for example, Estadistica de Los Ferrocarriles en Explotacion for a detailed report on the total expenses of railways in Argentina.
} 
are total expenses less spending on new capital goods. In these cases total expenses were estimated using data from countries that report both working and total expenses. ${ }^{11}$

Construction spending is usually provided separately and is not included in total expenses. Construction costs were expenses associated with building the track and purchasing land for the permanent way. Construction costs therefore increased as rail mileage grew, but they did not necessarily increase at a constant rate because the price of land, materials, and labor evolved over time.

The financial data on railways needs to be converted into real terms and into a common currency in order to be comparable across countries and over time. The approach used here is to first deflate expenses and construction costs in the domestic currency using a domestic consumer price index with base year 1905 and then convert the figures into 1905 British pounds using the official exchange rate for $1905 .^{12}$ Within a particular country the series will represent 'real' changes in the expenses of railways. Across countries the series will reflect differences in expenses valued at the exchange rate. The choice of the 1905 exchange rate matters little because most countries had a fixed exchange rate during the period under study. Moreover a different exchange rate for France or any other country will only scale the level of expenses in France upwards or downwards. In the subsequent efficiency analysis scalar changes in any variable will be absorbed into the country fixed effects. ${ }^{13}$

\footnotetext{
${ }^{11}$ Total expenses were estimated using working expenses and the predicted ratio of working to total expenses. The ratio of working to total expenses is fairly constant in most countries and averages 0.94 . To improve the estimate the effects of mileage growth were also incorporated. The predicted ratio in year $t$ was estimated to equal 0.94 0.0763*(Mileage Growth in year t). The appendix provides more details.

${ }^{12}$ Consumer Prices indices are generally drawn from Global Financial Database (GFD). The CPI was preferred to the GDP deflator because it is more readily available for the countries studied here. The exchange rates are available in the Statistical Abstracts. See the appendix for details on each country.

${ }^{13}$ Another possibility is to use PPP exchange rates. Williamson (1995) provides PPP exchange rates for a sample of countries around 1905. Total expenses for French railways in year $t$ could be converted to PPP adjusted British
} 


\subsection{Input Prices}

Different sources are needed to identify the prices of inputs—fuel, labor, and capital. Coal prices are used to measure the price of fuel because it was the primary source for most railways. Average coal prices are available for many countries in the Returns Relating to the Production and Consumption of Coal published by the British Board of trade. The Returns specify the 'pit-head' price of coal in shillings per metric ton for Britain, Russia, Sweden, Germany, Belgium, France, Spain, Austria, Hungary, Japan, the US, India, Canada, and Australia. For most years and countries the exchange rate was fixed so the series are effectively expressed as a domestic coal price series converted at the official exchange rate in 1905. The coal price series are deflated using the domestic consumer price index for each country to express coal prices in real terms. The Returns did not cover all countries for which there is railway data. Information on Dutch, Norwegian, Italian, and Argentine coal prices were taken from other sources which are described in the appendix.

The earnings of railway employees in the late 1900s are available for the US, Britain, Germany, and Italy in a report by the Bureau of Railway Economics (1912). The report shows that the average weekly earnings for railway employees were 54.2 shillings for the US, 25.6 shillings for Britain, 26 shillings for Germany, and 22.9 for Italy from 1905 to $1909 .{ }^{14}$ Williamson’s (1995, p.184) data shows that the average weekly earnings for skilled and unskilled builders in nominal terms were 98.1 and 59.4 shillings for the US, 37.7 and 25.6 for Britain, 28.5 and 21.8 for Germany, 14 and 9 for Italy. With the exception of Italy, the weekly

pounds by multiplying expenses by the formula: (PPP exchange rate pounds per franc 1905) *(CPI GB t)/(CPI France t). A comparison was made between the PPP adjusted total expenditure series and the deflated and converted series used in the analysis for the sample of countries in Williamson. The two series are not identical but they are highly correlated (the correlation coefficient is above 0.99 ). The reason is that the CPI for Britain is essentially constant for the period from 1883 to 1910 making the two series proportion to one another.

${ }^{14}$ Bureau of Railway economics wages were converted from dollars to shillings using the official exchange rate. 
earnings of the unskilled are similar to the figures for railway employees. Building on these data, wages for railway workers are measured using the weekly wages of unskilled labor in each country (see the appendix for sources). ${ }^{15}$ The wages are all deflated using a domestic consumer price index with base year 1905 and then converted to British shillings using the 1905 official exchange rate.

The user cost of capital is often represented by the expression $\frac{p^{k}}{p}(r+\delta)$, where $p^{k}$ is the price of capital goods, $p$ is the price of other goods in the economy, $r$ is the interest rate, and $\delta$ is the depreciation rate. ${ }^{16}$ The prices for new capital goods, like locomotives, and materials for repairs like timber, iron, steel, bricks, etc. are not available for most countries. Fortunately, materials for repairs to the track and stations were the same or similar as those used for construction of the track and station. Therefore the construction cost per mile provides a reasonable proxy for the average price of capital goods. Construction costs are published in the Statistical Abstracts for most countries. Secondary sources were used for Spain, Italy, and Belgium where construction costs are not reported (see the appendix for details). The average construction cost per mile was deflated and converted using the same procedures for wages and coal prices. The interest rate was assumed to equal the yield on government bonds, which are largely available in Global Financial Data. The depreciation rate was assumed to be $4 \%$ which reflects a 25 year life span for buildings and locomotives.

\subsection{Ownership Variables}

\footnotetext{
${ }^{15}$ In the analysis wages for skilled workers were also included as a robustness check but the results were unaffected.

${ }^{16}$ Collins and Williamson (2001) use a similar expression in their study of the user cost of capital .
} 
The Statistical Abstracts provide information on the number of miles belonging to the state and the number of miles belonging to companies in each country and year starting in the 1870s. The Report on State Railways, published by the Board of Trade, provides greater details on ownership and operational practices across countries in 1912. It indicates that private ownership and operation or state ownership and operation were the dominant forms. Only $3 \%$ of the world's railway miles were state-owned and privately-operated in 1912 and only 1\% were privately-owned and state-operated. ${ }^{17}$

The fraction of miles owned by the state provides a simple measure of the extent of state ownership in a country. It can be misleading though because it masks the sources of state ownership. The number of miles owned by the state can be decomposed into miles initially owned and constructed by the state plus miles nationalized minus miles privatized. ${ }^{18}$ These three variables are used to analyze state ownership because the effects can be different in each case. Table 1 summarizes the fraction of miles nationalized and constructed by the state in 1880 and 1910 for the sample of countries analyzed here. In 1880 nationalizations were rare outside of a few countries like Belgium, Germany, India, and Italy. The state constructed a relatively large proportion of the miles in some countries, including Norway, the Netherlands, Belgium, Argentina, Germany, and Australia. In others like Britain, Spain, and the US construction of state-owned railways was absent or negligible.

By 1910 nationalizations had become more common. State-takeovers affected a relatively large proportion of the miles in Russia, Belgium, Italy, and Germany. The most extreme cases were Japan, Switzerland, and Austria where over 50\% of all miles had been

\footnotetext{
${ }^{17}$ In the sample, the Netherlands, India, and Italy had some state-ownership and private operation. Norway and Austria had some private ownership and state operation.

${ }^{18}$ See Bogart (2009) for details on the measurement of nationalizations and state ownership.
} 
nationalized by 1910. The degree of state construction also differed across countries by 1910. In Russia, Germany, Italy, and India the state constructed a greater proportion of the mileage between 1880 and 1910 and private companies built a lower proportion. In Norway, Japan, Argentina, Canada, and Australia the opposite trend occurred. The state constructed a smaller proportion of the mileage, companies a greater proportion. Privatizations were rare in 1880. By 1910 they occurred in Argentina and to a lesser extent in France and the Netherlands.

Other variables are also incorporated as controls. The average elevation, the standard deviation of elevation, and the skew of elevation can be approximated using data from the Center for International Earth Science Information Network (CIESIN). ${ }^{19}$ CIESIN also provides data on the percentage of land area within $100 \mathrm{~km}$ of the coast. The number of miles of navigable rivers and canals is taken from Mulhall (1892, p. 102) and Vernon-Harcourt (1896). The average age of the network is calculated using the number of miles added in each year as an indicator for the ‘birth’ of track miles. GDP per capita and GDP per capita growth are available from Maddison (2003) and are expressed in 1990 PPP adjusted US dollars. ${ }^{20}$ The use of PPP dollars is not crucial in this context because the GDP figures are correlated with an index of inefficiency.

\section{Preliminaries}

There were substantial differences in the operating expenses of railways across countries and over time. Only some of these differences in costs can be explained by variation in scale,

\footnotetext{
${ }^{19}$ The land area of all countries was normalized to be 100 square meters. The number of square meters within an elevation class was assumed to be equal to the percentage of land in each elevation class. Land was assumed to be equal to the lower bound in its elevation class to simplify the calculations. Then average, standard deviation, and skew were calculated over the distribution. See Center for International Earth Science Information Network, Columbia University, 2007. National Aggregates of Geospatial Data: Population, Landscape and Climate Estimates, v.2 (PLACE II), Palisades, NY: CIESIN, Columbia University. Available at: http://sedac.ciesin.columbia.edu/place/. ${ }^{20}$ GDP data for Russia are taken from Gregory (1982).
} 
density, and input prices. This section illustrates these points and sets the stage for the estimation of inefficiency in the following section.

Figure 1 plots the natural log of total operating expenses against the natural log of ton miles shipped in 1910. Clearly the log of ton-miles explains a substantial portion of the variation in the log of total expenses. As the graph indicates total expenses were greatest in countries like the US, Germany, and Russia in large part because they had the greatest ton-miles. However, the graph also reveals that some countries had similar ton-miles, but total expenses differed.

Consider, for example, that total expenses are lower in India than Canada even though they have similar ton-miles.

There are other factors besides ton-miles that can explain differences in operating expenses across countries. Around 93\% of the variation in the natural log of total expenses can be explained by a pooled OLS regression that includes the log of ton miles, passenger miles, rail miles, unskilled wages, coal prices, and capital prices as right-hand side variables. Expenses were higher in countries with higher ton miles and passenger miles. Expenses were higher in countries with greater wages, coal prices, or capital costs. They were also higher in countries with a larger rail network all else equal.

Differences in scale, density, and input prices are clearly crucial factors, but they do not provide a complete characterization of expenses. As an illustration, figure 2 plots the residual of log expenses for Canada and India computed from the pooled regression. Canada's residual expenses are initially lower than India, but after the 1900s they rise rapidly. India's residual expenses decrease from the 1880s to the 1890s and are significantly below Canada by 1912 . 
The literature on efficiency estimation characterizes residual operating expenses into two main types: inefficiency and time-invariant heterogeneity. Inefficiency refers to the added expenses arising from the failure to adopt best-practice technologies or the misallocation of inputs. Time-invariant heterogeneity reflects fixed environmental factors which affect costs but are beyond the control of railway planners, managers, and employees. A goal of the estimation is to separate inefficiency from time-invariant heterogeneity. It is difficult to fault railway decision-makers if their geographic environment necessitated extra expenditures on labor, fuel, and capital. On the other hand they could be faulted if there were added expenses due to the failure to adopt technologies or misallocate inputs. Current estimation techniques allow the econometrician to separate inefficiency from all time-invariant heterogeneity by including fixed effects. Unfortunately, the techniques do not allow the econometrician to estimate inefficiency arising from culture and other institutional factors which do not evolve within the time-span of the observed data. The following section addresses these issues further and introduces the econometric methodology.

\section{Methodology for Estimating Inefficiency}

In the railway context, the translog is the most commonly-used cost function because it allows for flexible substitution between inputs. It also 'nests' the Cobb-Douglas cost function as a special case. In the main specification the translog cost function will be estimated using the 'true fixed effects' model taking the following form:

$$
\begin{aligned}
& \ln c_{i t}=\sum_{k=1}^{K} \beta_{k} \ln q_{i t}^{k}+\sum_{j=1}^{J} \beta_{j} \ln p_{i t}^{j}+0.5 \sum_{k=1}^{K} \sum_{l=1}^{K} \beta_{k l} \ln q_{i t}^{k} \ln q_{i t}^{l}+0.5 \sum_{j=1}^{J} \sum_{l=1}^{J} \beta_{j l} \ln p_{i t}^{j} \ln p_{i t}^{l}+ \\
& +\sum_{j=1}^{J} \sum_{k=1}^{K} \beta_{k j} \ln q_{i t}^{k} \ln p_{i t}^{j}+\mu_{1} t+\mu_{2} t^{2}+\alpha_{i}+u_{i t}+v_{i t}
\end{aligned}
$$


where $\ln c_{i t}$ is the natural $\log$ of real expenses for country i in year $\mathrm{t}, \ln q_{i t}^{k}$ is the $\log$ of output $\mathrm{k}$ (i.e. ton-miles, passenger-miles, and rail miles) for country $\mathrm{i}$ in year $\mathrm{t}, \ln p_{i t}^{j}$ is the $\log$ of the real price of input $\mathrm{j}$ (i.e. labor, fuel, and capital) for country $\mathrm{i}$ in year $\mathrm{t}, t$ and $t^{2}$ are the year and year squared respectively, $\alpha_{i}$ is a fixed effect for country i, $u_{i t}$ is a half-normal random variable with mean 0 and variance $\sigma_{u}^{2}$, and $v_{i t}$ is a normal random variable with mean 0 and variance $\sigma_{v}^{2}$. The term $u_{i t}$ measures cost inefficiency. It is restricted to positive values only and higher values correspond with higher costs. Cost inefficiency is estimated for each country and year using the composite error term $\varepsilon_{i t}=u_{i t}+v_{i t}$ and the parameter estimates for $\sigma_{u}^{2}$ and $\sigma_{v}^{2}$. The conditional mean for cost inefficiency is calculated using the following formula from Jondrow et. al. (1982):

$$
E\left[u_{i t} \mid \varepsilon_{i t}\right]=\frac{\sigma \lambda}{1+\lambda^{2}}\left[\frac{\phi(z)}{1-\Phi(z)}-z\right]
$$

where $\phi$ is the p.d.f of the standard normal, $\Phi$ is the c.d.f. of the standard normal, $\sigma=\sqrt{\sigma_{u}^{2}+\sigma_{v}^{2}}, \lambda=\frac{\sigma_{u}}{\sigma_{v}}, z=\frac{\varepsilon_{i t} \lambda}{\sigma}$, and $\varepsilon_{i t}=u_{i t}+v_{i t}$.

The true fixed effects model has two advantages over alternatives like the conventional fixed effects model and the pooled normal half-normal model. ${ }^{21}$ First, it allows cost inefficiency to be time-varying. Second, the country fixed effect separates inefficiency $u_{i t}$ from timeinvariant heterogeneity $\alpha_{i}$. The conventional fixed effects model yields an estimate of the average difference in expenses through the coefficients for the fixed effects, but by definition it cannot capture changes in efficiency over time. A pooled half-normal model, which drops the

\footnotetext{
${ }^{21}$ See Greene (2005) for an extensive discussion of the advantages of the true fixed effects model and Farsi, Fillipini, and Greene (2005) for one of the first studies to use true fixed effects and true random effects models to estimate cost inefficiency in railways.
} 
country fixed effects, is less ideal because it conflates inefficiency and time-invariant heterogeneity like geography.

\section{Cross-Country Inefficiency Estimates}

Table 2 reports the average inefficiency estimate by country in the 1880s, 1890s, and 1900s. It also lists the rankings from the most efficient to the least efficient in the 1900s. The results show that the US, France, Belgium, and the Netherlands had the most efficient railway sectors in the 1900s. The estimates imply that railway operating expenses could have been reduced by $4.2 \%$ if all inefficiency were eliminated in the US. Interestingly, the US, France, Belgium, and the Netherlands were among the least inefficient in the 1890s. For the Netherlands this represented a reversal of its earlier status as the most efficient in the 1880s.

There were a large number of countries with 'medium' inefficiency in the 1900s. Russia and Australia had an average inefficiency of 0.051 and 0.052; Britain and India had 0.055 and 0.056; Norway and Spain had 0.057 and 0.058; Argentina and Germany both had an average inefficiency of 0.059. The trends were varied in this group. Britain, Germany, and Argentina's inefficiency increased throughout the period. In India, Norway, and Spain it tended to decrease over time. India's efficiency improvements are evident in figure 2 which shows that its residual costs decreased from the 1880 s to the 1890 s.

Canada and Italy had the least efficient railway sectors in the 1900s. The estimates suggest that both countries could have reduced their expenses by at least 7.3\% if they eliminated all inefficiency. Both arrived at this point because their inefficiency increased in the 1900s. Canada's rising inefficiency is evident in figure 2 which shows that Canada's 'residual' expenses 
were rising in the 1900s. Japan, Switzerland, Austria, and Sweden were slightly more efficient than Canada and Italy. In all four countries inefficiency increased from the 1890s to the 1900s.

The results show that the most efficient railway sectors in the 1880s or 1890s were not necessary the most efficient by the 1900s. The correlation between cost inefficiency in the 1880s and 1890s is negative (see the bottom of table 2). The same is true of the correlation between cost inefficiency in the 1890s and 1900s. This pattern suggests that greater efficiency was in many cases replaced by greater inefficiency.

The estimated inefficiency differences across countries are robust to different specifications. Table 3 reports the summary statistics of inefficiency for alternative specifications like the Cobb-Douglas, the Cobb-Douglas assuming homogeneity of degree one in input prices, and the translog without country fixed effects. ${ }^{22}$ It also reports the correlation of the inefficiency estimates between the translog model with country fixed effects and the rest. The mean inefficiency estimates are similar between the Cobb-Douglas models and the translog model with country fixed effects (see columns 1 to 3). More importantly the inefficiency estimates are highly correlated across these three specifications. This suggests that the estimates are fairly consistent on which countries had relatively high efficiency and which had relatively low efficiency.

The inefficiency estimates are different in the translog model without country fixed effects. Column (4) in table 3 shows that the mean and standard deviation of inefficiency is higher in this model. Nevertheless there is a reasonably high correlation between the translog

\footnotetext{
${ }^{22}$ In addition, alternative distributions were tried such as the Gamma and Exponential but the estimates could not be computed. This is not a major concern because most studies find the inefficiency estimates to be similar in the halfnormal model compared to the Gamma or Exponential.
} 
models with and without country fixed effects. Thus inefficiency levels differ in the two models, but the inefficiency differences across countries and over time are similar.

The inefficiency estimates from the translog model without country fixed effects are of additional interest. They should not be interpreted as inefficiency in a strict sense because they conflate time-invariant heterogeneity, like geography, with the failure to adopt new technologies or the misallocation of inputs. Nevertheless they do provide a useful metric for the residual differences in operating expenses across countries. Table 4 reports the average 'inefficiency' estimate by country in the 1880s, 1890s, and 1900s. The rankings of the countries are generally the same. The US, France, and Belgium still have low inefficiency in the 1900s; Canada and Italy have high inefficiency in the 1900s. The most notable changes are the Netherlands, whose inefficiency is now higher, and Japan, Switzerland, and Sweden, whose inefficiency is now lower.

The estimates of the cost function are also of interest. Table 5 shows the coefficient estimates for the translog model with country fixed effects. For comparison, results from the Cobb-Douglas model with country fixed effects are also reported. The coefficients give the percentage increase in total costs for a one percent increase in outputs, rail miles, or input prices. The estimates for the translog model show that the cost elasticity with respect to outputs and rail miles are not constant. The cost elasticity for ton miles and passenger miles evaluated at the mean values for all other variables are 0.51 and 0.42 , respectively. These figures imply modest economies of scale in the 'average' country. The cost elasticity with respect to rail miles evaluated at the mean was 0.23 . This figure implies that if rail miles grew at the same rate as ton- 
miles and passenger miles then average costs would rise rather than decrease. ${ }^{23}$ This suggests there were economies of density in the railway sector.

The coefficients in the translog model also imply that the cost elasticity of ton miles or rail miles increased as ton miles or rail miles increased. At one standard deviation below the mean value for ton miles, the cost elasticity for ton miles is 0.37 and at one standard deviation above the mean for ton miles the elasticity is $0.65 .^{24}$ The cost elasticity of passenger miles was different because it decreased as passenger miles increased. At one standard deviation below the mean value for passenger miles, the cost elasticity is 0.47 and at one standard deviation above the mean the elasticity is 0.37 . Together these results imply that economies of scale and density could vary substantially. They were greatest in smaller networks with low levels of ton-miles and high-levels of passenger miles.

The cost elasticity for coal prices, wages, and capital prices evaluated at the mean values for all other variables are $0.25,0.32$, and 0.25 , respectively. All three vary with output and rail miles, but not with other inputs. ${ }^{25}$ For example, the cost elasticity for coal prices was higher when ton miles were higher, but it was lower when passenger miles and rail miles were higher. This may reflect differences in the technology of providing freight and passenger services.

Lastly, the time trend coefficients in the translog model suggest that operating costs decreased over time. In 1890 costs were 10\% lower than in 1882; in 1900 costs were 19\% lower than in 1882, and in 1910 they were $22 \%$ lower than in 1882. These figures suggest that the

\footnotetext{
${ }^{23}$ For example, if ton-miles, passenger miles, and rail miles all increased by $1 \%$ in the average country then costs would rise by $0.51 \%+0.42 \%+0.23 \%=1.16 \%$.

${ }^{24}$ The elasticity calculations use the average standard deviation in ton miles within countries rather than across countries. At one standard deviation below the mean value for rail miles, the cost elasticity is 0.19 and at one standard deviation above the mean for rail miles the elasticity is 0.27 .

${ }^{25}$ The coefficients on the interactions between input prices are all insignificant indicating that a unit-elasticity of substitution between inputs cannot be rejected.
} 
world's railway sector was experiencing relatively rapid technological change in the 1880s and 1890s. The implied annual rate of total factor productivity (TFP) growth attributable to technological change was $1.2 \%$ per year from 1882 to 1900 . In the 1900s TFP growth attributable to technological change seems to have fallen substantially to around $0.3 \%$ per year.

Inefficiency is linked with the rate of TFP growth in individual countries. A decrease in the inefficiency score of a country would imply that it experienced an even faster rate of TFP growth than the one implied above, while an increase in inefficiency would imply a lower rate of TFP growth (Kumbhaker and Lovell 2000, p. 289). It is important therefore to identify which factors influenced inefficiency across countries and time periods. The following section focuses on the role of state ownership.

\section{State Ownership and Inefficiency}

State ownership was on the rise from the 1880s to the 1900s. Commentators at the time consistently pointed to the choice between state or private ownership as being one of the most important policy decisions facing the railway sector. Theories of the firm also point to the importance of private or state ownership. The literature suggests that ownership defines residual control rights and therefore alters managers, planners, and regulators incentives to make noncontractual investments which improve efficiency (Shleifer 1998). The goal here is to test whether different forms of state ownership had an effect on inefficiency. The effect is assessed by a regression of inefficiency in country i and year t on variables measuring the extent of nationalizations, privatizations, and state railway construction. The first specification includes control variables for elevation, navigable rivers, the percentage of land area within $100 \mathrm{~km}$ of the coast, the average age of the track mileage, GDP per capita, and GDP per capita growth. The 
second set of specifications also includes country fixed effects, country specific time trends, and year fixed effects.

Table 6 shows the results focusing on the cross-country variation. Column (1) reports estimates using the broadest measure of state ownership: the fraction of miles owned by the state. In this specification, and in all others, the inefficiency estimates come from the baseline translog model summarized in table 2 . The results suggest that countries with greater state ownership did not have significantly higher inefficiency. By itself this finding is difficult to interpret because state ownership came in various forms. In column (2) state ownership is decomposed into the fraction of miles nationalized, the fraction constructed by the state, and the fraction privatized. Column (3) does the same after adding the control variables. In both specifications nationalizations and privatizations are associated with higher inefficiency and greater state railway construction is associated with lower inefficiency, but none of the coefficients is statistically significant. ${ }^{26}$

The preceding analysis does not take into account differences in the average level of inefficiency across countries, differences in inefficiency trends across countries, or year specific shocks to inefficiency. The specifications in table 7 account for these factors by including country fixed effects, country specific time trends, and year fixed effects. ${ }^{27}$ The results in column (1) show that the effects of ownership are more evident once these factors are controlled for. There is a positive and significant relationship between inefficiency and the fraction of miles nationalized, suggesting that inefficiency increased as nationalizations increased within a

\footnotetext{
${ }^{26}$ The results for the control variables are not reported to save space. Only the average age was statistically significant. The coefficient was negative implying that countries with older track mileage were less inefficient. ${ }^{27}$ Although the inefficiency estimates are derived from a translog model with country fixed effects, this does not imply that country-specific trends or year specific shocks have been purged from inefficiency. Therefore country fixed effects, country specific time trends, and year fixed effects can still be included in the regression.
} 
country. There is also a negative and significant relationship between inefficiency and the fraction of miles constructed by the state, suggesting that inefficiency decreased as state (opposed to private) railway construction increased within a country. Lastly, there is no significant relationship between privatizations and inefficiency.

The same conclusions are suggested by the results in columns (2), (3), and (4). In (2) the error term in the regression is assumed to be first-order autoregressive and corrects for problems of serial correlation. The coefficient estimates and their significance are largely unaffected, except for the privatization variable. In (3) a Tobit specification is used to correct the standard errors for the truncation of the inefficiency index. The coefficient estimates and their significance are unaffected once again. In (4) the left-hand side variable is replaced by the inefficiency estimate from the translog model without country fixed effects. Here the estimates show an even stronger relationship between nationalizations, greater state railway construction, and inefficiency. ${ }^{28}$

The estimates for the nationalization and state railway construction variables are generally similar when individual countries are dropped. For example, the estimates are largely unchanged when India or Italy are dropped. Both had significant state ownership and private operation. The estimates are also similar when Norway or Austria are dropped. Both had significant private ownership and state operation. The results are sensitive to the exclusion of one country: the Netherlands. The Netherlands is an interesting case because its inefficiency varied significantly over time and therefore its changes in inefficiency are perhaps an outlier. Column (5) in table 7 shows results after dropping the Netherlands from the estimation. The coefficient

\footnotetext{
${ }^{28}$ The results for the control variables are not reported to save space. They show that inefficiency did not increase as a countries' network aged or if its GDP per capita growth was higher. The results show that increases in GDP per capita were associated with higher inefficiency. It is not immediately obvious though why greater income per capita contributed to higher inefficiency. Further study is needed before firm conclusions can be drawn.
} 
on the nationalization variable drops from 0.109 to 0.069 and the coefficient on state railway construction decreases in absolute terms from -0.54 to -0.205 . Despite their lower magnitude both ownership variables remain statistically significant. The counterfactual analysis below also demonstrates their economic significance.

The regressions controls for a variety of factors including country fixed effects, year fixed effects, and country-specific time trends. Still there might be a concern that the estimated relationship between state ownership and inefficiency is biased because ownership changes are endogenous. This issue cannot be fully resolved here, but some insights can be gained by examining the trends in inefficiency prior to nationalizations and privatizations. ${ }^{29}$ If nationalizations were preceded by greater inefficiency then this would suggest they were a response to greater inefficiency rather than a contributing factor. The same could be said if privatizations were preceded by greater inefficiency.

The specifications in table 8 address this issue by examining the relationship between inefficiency and the fraction privatized or nationalized one, two, or three years before they occurred. The fraction privatized is positive and significant two or three years before they occurred. This finding suggests that privatizations may have been a policy response to inefficiency problems in the railway sector. The results suggest a different interpretation for nationalizations. The coefficient for the fraction nationalized one year before is positive and significant, but the coefficients for the fraction nationalized two or three years before are insignificant and small in magnitude. These findings indicate there is little evidence that greater inefficiency preceded the announcement to nationalize. The process of nationalization often

\footnotetext{
${ }^{29}$ Another approach would be to use instrumental variables for ownership changes. Some instruments for nationalizations have been proposed in Bogart (2009) but the variation in the instruments was too small for the sample of countries here.
} 
took a year to implement. Japan's nationalization, for example, was authorized by a law passed in 1906 (Ericson 1996). The assets were transferred from private companies to the state in 1907 and 1908, which is when the nationalization is dated in the data. If nationalizations were a response to inefficiency, then inefficiency should begin to rise before nationalizations were announced. The regressions show this was not the case.

Figure 3 further illustrates the relationship between inefficiency and nationalizations by plotting inefficiency three years before and three years after five major nationalizations: Russia 1894, France 1908, Switzerland 1902, Japan 1907, and Austria 1908. In all cases inefficiency is relatively stable prior to the year before the nationalization and then rises afterwards.

Another issue concerns the long-term effects of nationalizations. Table 9 includes an interaction between the year and the fraction of miles nationalized to investigate whether the trend in inefficiency changed after nationalization. The coefficient on the interaction term is negative and significant, implying that the trend in inefficiency was downward following nationalizations. Notice however that the downward trend was quite gradual. The estimate implies that ten-years later only half of the increase in efficiency from nationalizations was eliminated. The results in column (2) suggest a similar conclusion. The specification includes a variable for the fraction nationalized correctly dated and a variable for the fraction nationalized 3 years after it is dated. The coefficient on the latter variable is -0.034 , suggesting that inefficiency decreased three years after nationalization, but it is not statistically significant.

The trends in inefficiency before greater state or private railway construction are more difficult to characterize because the fraction of miles constructed by the state evolved slowly through new additions to the network. That being said, there were some years with larger 
increases or decreases in miles constructed by the state or companies. For example, in Japan the fraction constructed by the state decreased from 0.252 to 0.224 between 1897 and 1898, indicating a large increase in private rail construction. Studying these cases can give some indications of the trends in inefficiency prior to 'large' increases in private or state railway construction.

The data indicate that the average standard deviation in the fraction constructed by the state within countries was 0.023 . Based on this figure, a large increase in state railway construction is defined as a year in which the fraction of miles constructed by the state increased by more than 0.023 . Similarly, a large increase in private railway construction is defined as a year in which the fraction of miles constructed by the state decreased by more than 0.023 . The specifications in table 10 include a dummy variable for years with a large increase in private or state railway construction, dummy variables for all three years before, and dummy variables for all three years after. The results provide a similar interpretation as figure 3 which plots inefficiency three years before and after major nationalizations

The results show that large state railway construction was preceded by rising inefficiency and that large private construction was not preceded by any statistically significant change in inefficiency. These findings suggest that a greater fraction of miles constructed by the state did not reflect a pre-existing trend towards lower inefficiency. ${ }^{30}$ In addition, the results show that inefficiency increased in the years following large private railway construction and inefficiency decreased in years following large state construction. These findings further support the earlier result that a greater fraction of miles constructed by the state lowered inefficiency.

\footnotetext{
${ }^{30}$ If that were the case then inefficiency should have risen before large private construction and inefficiency should have decreased before large state construction. This was not the case.
} 
Overall the results point to the conclusion that the rise of state ownership had different effects depending on the way it was implemented. Inefficiency generally increased when the state nationalized private railway companies and inefficiency generally decreased when the state built more new railway lines than private companies. These findings naturally raise the question of whether state ownership contributed to greater or lower inefficiency in most economies. This issue can be addressed by a counterfactual analysis in which nationalizations are assumed to be absent. Columns (1) and (2) in table 11 compare the average level of inefficiency from 1900 to 1912 in each country with the estimated level of inefficiency assuming there were no nationalizations. The counterfactual inefficiency is calculated by multiplying the fraction of miles nationalized in 1910 by the coefficient for the fraction nationalized in column (5) of table 7. ${ }^{31}$ The results show that inefficiency would have been substantially lower in some countries. For example, inefficiency would have been more than 50\% lower in Switzerland, Austria, and Japan without nationalizations. Despite such cases nationalizations had a relatively small impact on inefficiency when viewed from a global perspective. The bottom of table 11 reports the average inefficiency without nationalizations, where each country's inefficiency is weighted by the size of their railway network. The estimates imply that the average inefficiency would have been 0.045 without nationalizations instead of 0.051 with nationalizations. The small difference partly reflects the fact that the U.S.—-the world's largest railway country-had no nationalizations and suffered no increase in inefficiency.

The effects of greater state railway construction are estimated through a counterfactual in which there was far less state railway construction and far more private railway construction. In the sample of countries, the average fraction of miles constructed by the state was approximately

\footnotetext{
${ }^{31}$ For simplicity the counterfactual omits the gradual decrease in inefficiency following nationalizations shown in table 9. Including this extra effect should not affect the estimates for most countries.
} 
0.25 by 1910. Column (3) in table 11 reports the average inefficiency level from 1900 to 1912 if Austria, Japan, Sweden, Italy, Belgium, Russia, the Netherlands, Germany, India, Norway, and Australia had only $25 \%$ of their rail miles constructed by the state instead of their observed level reported in table $1 .^{32}$ All countries with less than $25 \%$ state construction were assumed to have the same. The results show that inefficiency would have been substantially higher in a number of countries with less state railway construction and more private railway construction. In Australia, Norway, India, and Germany inefficiency would have doubled or tripled. Across the sample of countries the level of inefficiency would have been substantially higher as well. The average inefficiency with no country having more than $25 \%$ state rail construction would have been 0.071 instead of the observed average of 0.051 .

The last column in table 11 reports the net change in inefficiency if there were no nationalizations and no country had more than $25 \%$ state rail construction. Inefficiency would have been lower in countries with substantial nationalizations and higher in countries with substantial state railway construction. Most interestingly, the calculations show that the average inefficiency across countries would have been higher in the counterfactual with less state ownership. In other words, the rise of state ownership generally lowered inefficiency across the most important railway countries by 1910 .

\section{Conclusion}

Railway inefficiency could impose significant costs on economies in the early twentieth century not only because the railway sector was relatively large, but also because railways had spillover effects on the rest of the economy. This paper estimates inefficiency using stochastic

\footnotetext{
${ }^{32}$ The effect of lower state railway construction is calculated using the estimate in column (5) of table 7.
} 
frontier models and cross-country data on railway outputs and costs. The results show there were significant differences in inefficiency across countries and over time. The US, Belgium, France, and the Netherlands had the most efficient railway sectors by the 1900s, but none of these four countries was in the top ranks of efficiency in the 1890s.

The paper also shows that the rise of state ownership had different effects on inefficiency depending on the way it was implemented. Inefficiency generally increased when the state nationalized private railway companies and inefficiency generally decreased when the state built more new railway miles than private companies. A counterfactual analysis suggests that the net effect of greater state ownership was to lower inefficiency across the most important railway economies by 1910 .

More broadly the results speak to the effects of policy choices in the period from 1880 to 1912. State ownership of railways provides one example of greater state intervention in the economy. Future research should compare the effects of railways policies with other sectors to provide a general assessment of the state's role in economic development before World War I. 


\section{Data Appendix by Country}

Russia. The complete data cover the years from 1891 to 1907. The Statistical Abstracts provide data on railway miles, passengers carried, average journey, tons shipped, average haul, total expenses, and train miles from 1899 to 1910. Expenses are converted into British pounds using the official exchange rate of 0.105 pounds for one Rouble in 1905 . The 1899 figures for the average haul and the average journey were assumed to apply for the years 1891 to 1898 . Ton miles and passenger miles are calculated by multiplying tons by the average haul and passengers by the average journey. Coal prices per metric ton are reported in Returns relating to the Production, Consumption, etc. of Coal from 1891 to 1907. The prices are reported as average values in shillings. The official exchange rate was essentially constant (0.10 from 1891 to 1896 and 0.105 from 1897 to 1907) so the reported coal price series is already expressed in shillings at the 1905 official exchange rate. Weekly wages for unskilled and skilled workers are based on the real annual earnings of building and railroad staff reported in Allen (2003, p. 38). The series were converted into weekly nominal earnings using Gregory’s (1982) retail price index and then converted into British shillings using the 1905 exchange rate. Construction costs per mile were estimated using Mulhall’s (1892) construction cost figure in 1888 and Gregory (1982) annual series on railway investment from 1888 to 1907 . Gregory’s annual investment series is converted to 1905 shillings using the exchange rate. Mulhall's figure for construction is already expressed in British pounds. All financial variables are deflated using the retail price index from Gregory (1982) which was converted to the base year 1905. Bond yields come from the Russia 5s of 1822 in London. They are available in GFD which uses the Economist and Banker's Magazine (1844-1928). 
Norway: The complete data cover the years from 1880 to 1912. The Statistical Abstracts provide data on railway miles, passengers carried, tons shipped, total expenses, train miles, and construction costs. Expenses and construction costs are converted into British pounds using the official exchange rate of 0.056 pounds per Kroner in 1905. Ton miles and passenger miles are taken from Mitchell (1992). Coal prices per metric ton were provided by Ola H Grytten. They were converted into British pounds using the 1905 official exchange rate. Weekly wages for unskilled and skilled workers are based on day wages for workers in road construction and railway staff in Grytten (2007 pp. 281-282, 315-316). The wages are converted into British shillings using the 1905 exchange rate. All financial variables are all deflated using the Norwegian consumer price index from Grytten (2004) with base year 1905. Yields are taken from the 10-year government bond. They are available in GFD and are drawn from The Economist (1876-1917).

Sweden: The complete data cover the years from 1896 to 1912. The Statistical Abstracts provide data on railway miles, passengers carried, tons shipped, total expenses, train miles, and construction costs. Expenses and construction costs are converted into British pounds using the official exchange rate of 0.056 British pounds per Kronor. Ton miles and passenger miles are taken from Mitchell (1992). Coal prices per metric ton are reported in Returns relating to the Production, Consumption, etc. of Coal from 1896 to 1912. The prices are reported as average values in shillings. The official exchange rate was constant from 1896 to 1912 so the reported coal price series is already expressed in shillings at the 1905 official exchange rate. Weekly wages for unskilled and skilled workers are taken from the yearly wages of workers in sawmills and engineering listed in Bjorklund and Stenlund (1995, p.253). Wages are converted into shillings using the 1905 exchange rate. All financial variables are deflated using the Swedish 
consumer price index from Mitchell (1992) with base year 1905. Yields are taken from the 10year government bond. They are available in GFD and are drawn from The Economist (18681918).

Netherlands: The complete data cover the years from 1884 to 1902, 1904, 1906, and 1910. The Statistical Abstracts provide data on railway miles, passengers carried, tons shipped, total expenses, train miles, and construction costs (state railways only). Expenses and construction costs are converted into British pounds using the official exchange rate of 0.083 British pounds per Guilden. Ton miles and passenger miles are taken from Mitchell (1992). Coal prices are provided by Arthur van Riel through the Global Price and Income History Group (http://iisg.nl/hpw/data.php\#netherlands). The official exchange rate was constant from 1884 to 1910 so the reported coal price series is already expressed in shillings at the 1905 official exchange rate. The wages for unskilled and skilled workers are based on day wages for laborers and craftsman in Amsterdam (Allen 2001). The wages of builders are converted into an index with base year 1905 and multiplied by the weekly earnings of unskilled workers in 1905 shillings, which is estimated using Williamson's figures for the Netherlands and Britain (1995). The wages for skilled workers are equal to the weekly wages of unskilled in shillings multiplied by the ratio of craftsman to builders wages. All financial variables are deflated using the Dutch consumer price index from Mitchell (1992) with base year 1905. Yields are taken from the 10year government bond. They are available in GFD which uses the Economist and Banker's Magazine (1844-1928).

Belgium: The complete data cover the years from 1883 to 1910 except 1903 and 1908 . The Statistical Abstracts provide data on railway miles, passengers carried, tons shipped, total expenses, and construction costs. Expenses and construction costs are converted into British 
pounds using the official exchange rate of 0.04 British pounds per Belgian Franc in 1905. The Statistical Abstracts provide the average journey from 1901 to 1912 and the average haul in 1908, 1911, and 1912. The average journey in 1901 was assumed to apply to the period from 1883 to 1900 . The average haul in 1908 was assumed to apply for the entire period from 1883 to 1910. Ton miles and passenger miles are then calculated by multiplying tons by the average haul and passengers by the average journey. The Statistical abstracts provide information on train miles for all railways from 1901 to 1910 and for state railways from 1883 to 1902 . Total train miles from 1883 to 1900 are assumed to grow at the same annual rate as state railway train miles. Coal prices per metric ton are reported in Returns relating to the Production, Consumption, etc. of Coal from 1884 to 1912. The prices are reported as the average value 'when on the truck for transportation' in shillings. The official exchange rate was constant from 1883 to 1912 so the reported coal price series is already expressed in shillings at the 1905 official exchange rate. Weekly earnings for unskilled and skilled workers is based on the nominal annual earnings for manufacturing workers and civil servants in Scholliers (1995, p. 204). The weekly earnings are converted to shillings using the 1905 exchange rate. All financial variables are deflated using the Belgian consumer price index from Mitchell (1992) with base year 1905. Yields are taken from the 10-year government bond. They are available in GFD which uses the Economist and Banker’s Magazine (1845-1898).

France: The complete data cover the years from 1883 to 1911. The Statistical Abstracts provide data on railway miles, passengers carried, tons shipped, total expenses, train miles, and construction costs. Expenses and construction costs are converted into British pounds using the official exchange rate of 0.04 British pounds per French Franc in 1905. Ton-miles and passenger-miles are taken from Mitchell (1982). Coal prices per metric ton are reported in 
Returns relating to the Production, Consumption, etc. of Coal from 1884 to 1912. The prices are reported as the average value at the pit's mouth in shillings. The official exchange rate was constant from 1883 to 1912 so the reported coal price series is already expressed in shillings at the 1905 official exchange rate. The wages for unskilled and skilled workers are based on the day wages for laborers and craftsman in Paris (Allen 2001). The wages of builders are converted into an index with base year 1905 and multiplied by the weekly earnings of unskilled workers in 1905 shillings from Williamson (1995). The wages for skilled workers are equal to the weekly wages of unskilled in shillings multiplied by the ratio of craftsman to builders’ wages. All financial variables are deflated using the French consumer price index from Mitchell (1992) with base year 1905. Yields are taken from the 10-year government bond. They are available in GFD which uses Investor's Monthly Manual, London, The Economist (1866-1873), and L'Economiste Francais (1874-1897).

Switzerland: The complete data cover the years from 1894 to 1912. The Statistical Abstracts provide data on railway miles, passengers carried, tons shipped, total expenses, train miles, and construction costs. Expenses and construction costs are converted into British pounds using the official exchange rate of 0.04 British pounds per Swiss Franc in 1905. Ton miles and passenger miles are then calculated by multiplying tons by the average haul and passengers by the average journey. The Statistical abstracts report average haul and the average journey for 1906 to 1912. The average haul and journey in 1906 was assumed to apply for the whole period from 1894 to 1912. Coal prices are published in Siegenthaler (1996) and were converted to shillings per ton using the 1905 exchange rate. The wages for unskilled and skilled workers are based on the day wages for laborers and craftsman (Studer forthcoming). The wages are converted in 1905 shillings per week using the exchange rate. All financial variables are deflated using the Swiss 
consumer price index from Mitchell (1992) with base year 1905. Yields on government bonds come from Flandreau and Zumer (2004).

Spain: The complete data cover the years from 1884 to 1909. The Statistical Abstracts provide data on railway miles, passengers carried, tons shipped, and total expenses. The statistical abstracts provide data on total expenses from 1898 to 1909. For earlier years total expenses are estimated from working expenses using the formula discussed in the text. Expenses are converted into British pounds using the official exchange rate of 0.04 British pounds per Pesetas in 1905. Ton-miles and passenger-miles are taken from Mitchell (1982). Construction costs per mile were estimated using Mulhall’s (1892) figure of construction costs in 1880 and HerranzLocain’s (2005) annual series on railway investment from 1880 to 1909. Herranz's annual investment series is converted to 1905 shillings using the exchange rate. Mulhall's figure for construction is already expressed in British pounds. Coal prices per metric ton are reported in Returns relating to the Production, Consumption, etc. of Coal from 1884 to 1912. The prices are reported as the average value at the pit's mouth in shillings. The official exchange rate was constant from 1884 to 1909 so the reported coal price series is already expressed in shillings at the 1905 official exchange rate. The wages for unskilled and skilled workers are based on the day wages for laborers and craftsman in Madrid (Allen 2001). The wages of builders are converted into an index with base year 1905 and multiplied by the weekly earnings of unskilled workers in 1905 shillings from Williamson (1995). The wages for skilled workers are equal to the weekly wages of unskilled in shillings multiplied by the ratio of craftsman to builders' wages. All financial variables are deflated using the Spanish consumer price index from Flandreau and Zumer (2004) with base year 1905. Yields are taken from the 10-year government 
bond. They are available in GFD which uses Banker's Magazine and The Economist (18451910).

Italy: The complete data cover the years from 1890-91, 1898-1901, 1903, 1906, 1911. The Statistical Abstracts provide data on railway miles, passengers carried, tons shipped, train miles, and total expenses. Expenses and construction costs are converted into British pounds using the official exchange rate of 0.04 British pounds per Lire in 1905. Ton-miles and passenger-miles are taken from Mitchell (1982). Italian coal prices per ton are published in Cianci (1933). They are converted to British shillings using the 1905 exchange rate. The wages for unskilled and skilled workers are based on the day wages for construction and engineering (Scholliers and Zamagni 1995, p. 231). The wages are converted in 1905 shillings per week using the exchange rate. All financial variables are deflated using the Italian consumer price index from Mitchell (1992) with base year 1905. Yields are taken from the 10-year government bond. They are available in GFD which uses The Economist (1863-1914).

Japan: The complete data cover the years from 1894 to 1911. The Statistical Abstracts provide data on railway miles, passengers carried, tons shipped, total expenses, train miles, and construction costs. Ton miles and passenger miles are taken from Mitchell (1995). Expenses and construction costs are converted into British pounds using the official exchange rate of 0.102 British pounds per Yen in 1905. Coal prices per metric ton are reported in Returns relating to the Production, Consumption, etc. of Coal from 1894 to 1911. The prices are reported as the average market value in shillings. The exchange rate was essentially constant from 1894 to 1911 (0.105 in 1895 and 1896 and 0.108 in 1897) so the reported coal price series is essentially expressed in shillings at the 1905 official exchange rate. The wages for unskilled and skilled workers are based on day wages for laborers and craftsman (masons) in (Allen 2001), which are provided by 
David Jacks, Peter Lindert, and Salvadore Puente through the Global Price and Income History Group and are based on the Financial and Economic Annual of Japan. The wages are converted into shillings per week using the exchange rate in 1905. All financial variables are deflated using the Japanese consumer price index from Williamson listed in GFD with base year 1905. Yields are taken from the 10-year government bond. They are available in GFD which uses The Economist (1870-1914).

US: The complete data cover the years from 1883 to 1911. The Statistical Abstracts provide data on railway miles, passengers carried, passenger miles, tons shipped, ton miles, total expenses, train miles, and construction costs. Expenses and construction costs are converted into British pounds using the official exchange rate of 0.208 British pounds per dollar in 1905. Coal prices per metric ton are reported in Returns relating to the Production, Consumption, etc. of Coal from 1883 to 1911 . The prices are reported as the average spot value in shillings. The exchange rate was constant from 1883 to 1911 so the reported coal price series is expressed in shillings at the 1905 official exchange rate. The wages for unskilled and skilled workers are based on weekly earnings for low skilled labor and railway staff (Margo 2006). All financial variables are deflated using the US consumer price index from U.S. Government, Statistical Abstract of the United States listed in GFD with base year 1905. Yields are taken from the 10-year government bond. They are available in GFD which uses the Congressional Budget Office.

Argentina: The complete data cover the years from 1897 to 1912. The Statistical Abstracts provide data on railway miles, passengers carried, tons shipped, total expenses, train miles, and construction costs. Expenses and construction costs are converted into British pounds using the official exchange rate of 0.2 British pounds per peso in 1905. Ton miles, passenger miles, and average coal prices are taken from Estadistica de Los Ferrocarriles en Explotacion. Coal prices 
are converted in shillings using the 1905 exchange rate. The wages for unskilled and skilled workers are based on weekly earnings for railway construction workers and railway staff in Estadistica de Los Ferrocarriles en Explotacion. All financial variables are deflated using the Argentina consumer price index from Williamson (1995) with base year 1905. Yields are taken from the 10-year government bond. They are available in GFD which uses The Economist (18591930).

Britain: The complete data cover the years from 1883 to 1912. The Statistical Abstracts for the United Kingdom provide data on railway miles, passengers carried, tons shipped, train miles, and construction costs. Total expenses are estimated from working expenses using the formula discussed in the text. Ton miles and passenger miles are taken from Crafts, Mills, and Mulatu (2007). Coal prices per metric ton are reported in Returns relating to the Production, Consumption, etc. of Coal from 1883 to 1912. The prices are reported as the average value at the pit's mouth in shillings. The wages for unskilled and skilled workers are based on the day wages for laborers and craftsman in London (Allen 2001). The wages of laborers are converted into an index with base year 1905 and multiplied by the weekly earnings of unskilled workers in 1905 shillings from Williamson (1995). The wages for skilled workers are equal to the weekly wages of unskilled in shillings multiplied by the ratio of craftsman to builders' wages. All financial variables are deflated using the UK consumer price index from Mitchell (1992) with base year 1905. Yields are taken from the $2.5 \%$ consol. They are available in GFD which uses Central Statistical Office, Annual Abstract of Statistics, London: CSO (1853-1912).

Germany: The complete data cover the years from 1883 to 1912. The Statistical Abstracts provide data on railway miles, passengers carried, passenger miles, tons shipped, ton miles, total expenses, train miles, and construction costs. Expenses and construction costs are converted into 
British pounds using the official exchange rate of 0.08 British pounds per mark in 1905. Coal prices per metric ton are reported in Returns relating to the Production, Consumption, etc. of Coal from 1883 to 1912 . The prices are reported as the average value at the pit's mouth in shillings. The official exchange rate was constant from 1883 to 1912 so the reported coal price series is expressed in shillings at the 1905 official exchange rate. The wages for unskilled and skilled workers are based on the day wages for laborers and craftsman in Leipzig (Allen 2001). The wages of laborers are converted into an index with base year 1905 and multiplied by the weekly earnings of unskilled workers in 1905 shillings from Williamson (1995). All financial variables are deflated using the German consumer price index from Mitchell (1992) with base year 1905. Yields are taken from the 10-year bench-mark bond. They are available in GFD which uses the Bundesbank.

India: The complete data cover the years from 1891 to 1912. The Statistical Abstracts for British India provide data on railway miles, passengers carried, passenger miles, tons shipped, ton miles, train miles, and construction costs. Total expenses are estimated from working expenses using the formula discussed in the text. Expenses and construction costs are converted into British pounds using the official exchange rate of 0.067 British pounds per rupee in 1905. Coal prices per metric ton are reported in Returns relating to the Production, Consumption, etc. of Coal from 1883 to 1912 . The prices are reported as the average value at the pit's mouth in shillings using various exchange rates before 1898 and a constant exchange rate afterwards. Before 1898 Coal prices are converted back to rupees and then back to shillings using the official exchange rate in 1905. The wages for unskilled and skilled workers are based on the day wages for laborers and craftsman in five areas Karachi, Beglum, Ahmadgar, Bombay, and Ahmadbad. The wage data comes from the Statistical Abstract for British India. All financial variables are deflated using 
the Indian consumer price index from Department of Statistics, Commercial Intelligence Department listed in GFD with base year 1905. Yields are taken from the 10-year government bond. They are available in GFD which uses The Economist (1845-1920).

Canada: The complete data cover the years from 1886 to 1912. The Statistical Abstracts provide data on railway miles, passengers carried, tons shipped, train miles, and construction costs. Total expenses are estimated from working expenses using the formula discussed in the text. Expenses and construction costs are converted into British pounds using the official exchange rate of 0.205 British pounds per Canadian dollar in 1905. Coal prices per metric ton are reported in Returns relating to the Production, Consumption, etc. of Coal from 1886 to 1912. The prices are reported as the average value in shillings. The official exchange rate was constant from 1886 to 1912 so the reported coal price series is expressed in shillings at the 1905 official exchange rate. Wage rates for unskilled and skilled workers are taken from Historical Statistics of Canada and are converted to British pounds. All financial variables are deflated using the consumer price index from Minns and MacKinnon (2006) with base year 1905. Yields are taken from the 10-year government bond. They are available in GFD which uses The Bank of Canada.

Austria: The complete data cover the years from 1894 to 1910. The Statistical Abstracts provide data on railway miles, passengers carried, tons shipped, train miles, total expenses, and construction costs. Expenses and construction costs are reported in Gulden before 1900 and are converted into British pounds using the official exchange rate of 0.083 British pounds per Gulden. After 1905 expenses and construction costs are reported in Kronen and are converted into British pounds using the official exchange rate of 0.042 British pounds per Kronen. Ton miles and passenger miles are taken from Mitchell (1992). Coal prices per metric ton are reported in Returns relating to the Production, Consumption, etc. of Coal from 1883 to 1912. The 
prices are reported as the average value at the pit's mouth in shillings. The prices appear to be reported using the official exchange rate for Kronen. Weekly wages for unskilled workers are taken from Mesch (1984). They are converted into British pounds using the exchange rate from 1905. The wages for skilled workers are equal to the weekly wages of unskilled in shillings multiplied by the ratio of craftsman to builders’ wages in Leipzig drawn from Allen (2001). All financial variables are deflated using the Austrian consumer price index from Statistical Office, Statistische Nachrichten listed in GFD with base year 1905. Yields are taken from the 10-year government bond. They are available in GFD which uses The Economist (1874-1932).

Australia: The complete data cover the years from 1905 to 1912. The Statistical Abstracts provide data on railway miles, passengers carried, tons shipped, train miles, and construction costs. Total expenses are estimated from working expenses using the formula discussed in the text. Expenses and construction costs are expressed in British pounds. Coal prices per metric ton are reported in Returns relating to the Production, Consumption, etc. of Coal from 1883 to 1912. The prices are reported as the average value at the pit's mouth in shillings. Wages for unskilled and skilled workers are taken from the Statistical Abstracts for British Colonies. They are already expressed in British pounds. All financial variables are deflated using the Australian consumer price index from the Australian Bureau of Statistics, Digest of Current Economic Statistics listed in GFD with base year 1905. Yields are taken from the 10-year government bond. They are available in GFD which uses The Economist (1858-1931). 


\section{References}

Allen, Robert. “The Great Divergence in European Wages and Prices from the Middle Ages to the First World War.” Explorations in Economic History 38 (2001), pp. 411-447.

Arnold A. and S. McCartney. "Rates of return, concentration levels and strategic change in the British railway industry 1830-1913.” Journal of Transport History 25 (2005), pp. 41 60.

Bell, Horace. Railway Policy of India: With Map of Indian Railway System. Rivington,1894.

Bjorklund, Jorgen and Hans Stenlund. "Real Wages in Sweden, 1870-1950: a Study of six Industrial Branches.” In Scholliers, P. and Zamagni, V., Labour's Reward: Real Wages and economic change in $19^{\text {th }}$ and $20^{\text {th }}$ century Europe, New York: Edward Elgar, 1995.

Bogart, Dan. "Nationalizations and the Development of Transport Systems: Cross-Country Evidence from Railroad Networks: 1860-1912.” Journal of Economic History 69 (March 2009): 202-237.

British Board of Trade, The Statistical Abstract for the Principal and Other Foreign Countries, Various Years.

British Board of Trade, The Statistical Abstract for the Several Colonial and otherPossessions of the United Kingdom, Various Years.

British Board of Trade, The Statistical Abstract for the United Kingdom, Various Years.

British Board of Trade, Returns Relating to the Production and Consumption of Coal, Various Years. 
British Board of Trade. Report on State Railways: British Possessions and

Foreign Countries. London, 1913.

Bureau of Railway Economics. A Comparative Study of Railway Wages and the Cost of Living in The United States, the United Kingdom, and the Principal Countries of Continental Europe. New York, 1912.

Cantos, Pedro and Joaquin Maudos, "Regulation and Efficiency: the Case of European Railways,” Transportation Research Part A 35 (2001): 459-472.

Center for International Earth Science Information Network (CIESIN), Columbia University, 2007. National Aggregates of Geospatial Data: Population, Landscape and Climate Estimates, v.2 (PLACE II), Palisades, NY: CIESIN, Columbia University. Available at: http://sedac.ciesin.columbia.edu/place/.

Christopoulos, Dimitris, John Loizides, and Efthymios Tsionas. “Efficiency in European Railways: Not as inefficient as one might think,” Journal of Applied Economics 4 (May 2001): 63-88.

Cianci, Ernesto. Annali di Statistica series 6 Vol. 20 Rome: ISTAT, 1933.

Collins, William J. and Jeffrey G. Williamson. Capital-Goods Prices and Investment, 1870 1950. Journal of Economic History 61 (March 2001): 59-94.

Crafts, Nicholas, Terence C. Mills, and Abay Mulatu. "Total factor productivity growth on Britain’s railways, 1852-1912: A reappraisal of the evidence,” Explorations in Economic History 4 (Oct 2007): 608-634. 
Crafts, Nicholas, Timothy Leunig, and Abay Mulatu. "Were British Railway Companies Well Managed in the early twentieth Century?,” Economic History Review 61 (2008): 842-866.

Cunningham, William. Should our Railways be Nationalized? London, 1906.

Dunn, Samuel Orace. Government Ownership of Railways. New York, 1913.

Edwards, Clement. Railway Nationalizations. New York, 1907.

Ericson, Steven J. The Sound of the Whistle: Railroads and the State in Meiji Japan. Cambridge, 1996.

Farsi, Mehdi, Massimo Filippini, and William Greene. "Efficiency Measurement in Network Industries: Application to Swiss Railway Companies,” Journal ofRegulatory Economics 20 (2005): 69-90.

Flandreau, Mark and Frédréric Zumer. The Making of Global Finance, 1880-1913, OECD, 2004.

Foreman-Peck, James. "Natural Monopoly and Railway Policy in the Nineteenth Century.” Oxford Economic Papers 39 (1987): 699-718.

Greene, William. "Reconsidering Heterogeneity in Panel Data Estimation of the Stochastic Frontier Model,” Journal of Econometrics 126 (2005): 269-303.

Gregory, Paul. Russian National Income, 1885-1913. Cambridge: Cambridge University Press, 1982.

Grytten, Ola H. “Nominal wages in Norway 1726-1940 by occupation,” in Eitrheim, Øyvind, Jan T. Klovland and Jan F. Qvigstad (eds.). Historical Monetary Statistics for Norway 
Part II. Norges Bank Occasional Papers no. 38, 2007.

Grytten, O.H. "A consumer price index for Norway 1516-2003", 47-98, Historical Monetary Statistics for Norway 1819-2003, Norges Bank Occasional Papers no. 35, Oslo, 2004.

Herranz-Locan, Alfonso. “The Spanish Infrastructure Stock, 1844-1935.” Research in Economic History 23 (2005): 85-129.

Herranz-Locan, Alfonso. “Railroad Impact in Backward Economies: Spain, 1850-1913.” Journal of Economic History 66 (Dec. 2006): 853-881.

Jondrow, J., K. Lovell, I. Materov, and P. Schmidt. “On the Estimation of Technical Inefficiency in the Stochastic Frontier Production Function Model,” Journal of Econometrics 19 (1982): 233-238.

Kumbhaker, Subal and C.A. Knox Lovell. Stochastic Frontier Analysis. Cambridge: Cambridge University Press, 2000.

Leacy, F. H. Historical Statistics of Canada. Ottawa, 1983.

Leunig, Tim. "Time is Money: A Re-Assessment of the Passenger Social Savings from Victorian British Railways," The Journal of Economic History 66 (Sept. 2006): 653-673.

Lindert, Peter. Growing Public: Social Spending and Economic Growth since the Eighteenth Century. Cambridge, 2004.

MacKinnon, Mary and Chris Minns. "The Costs of Doing Hard Time: A Penitentiary based Regional Price Index for Canada, 1883-1923,” The Canadian Journal of Economics 40 (May 2007): 528-560. 
MacKinnon, Mary. “New Evidence on Canadian Wage Rates, 1900-1930,” The Canadian Journal of Economics 29 (Feb. 1996): 114-131.

Maddison, Angus. The world economy: historical statistics. Paris: Development Centre, OECD, 2003.

Margo, Robert A. , "Hourly and weekly earnings in selected industries and for lower skilled labor: 1890-1926.” Table Ba4314-4319 in Historical Statistics of the United States, Earliest Times to the Present: Millennial Edition, edited by Susan B. Carter, Scott Sigmund Gartner, Michael R. Haines, Alan L. Olmstead, Richard Sutch, and Gavin Wright. New York: Cambridge University Press, 2006. http://dx.doi.org/10.1017/ISBN 9780511132971.Ba4214-4544

Mesch, Michael. Arbeiterexistenz in der Spatgrunderzeit. Europaverlag Wien, 1984.

Millward, Robert. Private and Public Enterprise in Europe. Cambridge: Cambridge University Press, 2004.

Minister for Home Affairs, Australia. Year Book of the Commonwealth of Australia, 1910

Mitchell, B.R. International Historical Statistics: Africa, Asia, \& Oceania, 1750-1988. New York: MacMillan, 1995.

Mitchell, B.R. International Historical Statistics: The Americas, 1750-2000. New York: Palgrave MacMillan, 2003.

Mitchell, B.R. International Historical Statistics: Europe, 1750-1988. New York, MacMillan, 1992. 
Mulhall, Michael. Dictionary of Statistics. London: Routledge, 1892.

Parisio, Lucia. “A comparative Analysis of European Railway Efficiency: a cost frontier approach, Applied Economics 31 (1999): 815-823.

Raper, Charles Lee. Railway Transportation: a History of its Economics and its relation to the State. New York, Knickerbocker Press, 1912.

Republic of Argentina, Ministerio de Obras Publicas. Estadistica de Los Ferrocarriles en Explotacion, Various Years.

Shleifer, Andre. "State versus Private Ownership,” Journal of Economic Perspectives 12 (Fall 1998).

Scholliers, Peter. “A century of real industrial wages in Belgium, 1840-1939.” In Scholliers, P. and Zamagni, V., Labour's Reward: Real Wages and economic change in $19^{\text {th }}$ and $20^{\text {th }}$ century Europe, New York: Edward Elgar, 1995.

Siegenthaler, Hansjoerg. Historische Statistik der Schweiz Chronos, Zuerich, 1996.

Studer, Roman. "When Did the Swiss Get so Rich? Comparing Living Standards in Switzerland and Europe,” Forthcoming Journal of European Economic History.

U.S. Department of Commerce. Statistical Abstract of the United States, various years.

Vernon-Harcourt, Leveson Francis. Rivers and Canals. Oxford: Clarendon, 1896.

Williamson Jeffrey G. “The Evolution of Global Labor Markets since 1830: Background Evidence and Hypotheses,” Explorations in Economic History 32 (April 1995): 141 196. 
Table 1: Ownership Patterns across Countries: 1880 and 1910

\begin{tabular}{|c|c|c|c|c|c|}
\hline \multirow[b]{2}{*}{ Country } & \multicolumn{2}{|c|}{1880} & \multicolumn{3}{|c|}{1910} \\
\hline & $\begin{array}{c}\text { Fraction } \\
\text { miles } \\
\text { nationalized }\end{array}$ & $\begin{array}{c}\text { Fraction miles } \\
\text { constructed by } \\
\text { State } \\
\end{array}$ & $\begin{array}{c}\text { Fraction } \\
\text { miles } \\
\text { nationalized }\end{array}$ & $\begin{array}{c}\text { Fraction miles } \\
\text { constructed by } \\
\text { State } \\
\end{array}$ & $\begin{array}{c}\text { Fraction } \\
\text { miles } \\
\text { privatized } \\
\end{array}$ \\
\hline Russia & 0 & 0.04 & 0.19 & 0.44 & 0.01 \\
\hline Norway & 0 & 0.94 & 0 & 0.84 & 0 \\
\hline Sweden & 0 & 0.33 & 0.02 & 0.3 & 0 \\
\hline Netherlands & 0.01 & 0.57 & 0.07 & 0.52 & 0.04 \\
\hline Belgium & 0.24 & 0.44 & 0.43 & 0.5 & 0.01 \\
\hline France & 0.02 & 0.07 & 0.12 & 0.1 & 0.04 \\
\hline Switzerland & 0 & 0 & 0.53 & 0.06 & 0 \\
\hline Spain & 0 & 0 & 0 & 0 & 0 \\
\hline Italy & 0.22 & 0.22 & 0.35 & 0.45 & 0.01 \\
\hline Japan & 0 & 1 & 0.55 & 0.35 & 0 \\
\hline US & 0 & 0 & 0 & 0 & 0 \\
\hline Argentina & 0.01 & 0.48 & 0.01 & 0.24 & 0.12 \\
\hline Britain & 0 & 0 & 0 & 0 & 0 \\
\hline Germany & 0.13 & 0.51 & 0.26 & 0.68 & 0 \\
\hline India & 0.17 & 0.34 & 0.22 & 0.67 & 0 \\
\hline Canada & 0 & 0.16 & 0 & 0.07 & 0 \\
\hline Austria & 0.01 & 0.07 & 0.55 & 0.31 & 0.03 \\
\hline Australia & 0.02 & 0.92 & 0.02 & 0.86 & 0 \\
\hline
\end{tabular}

Sources: Bogart (2009). 
Table 2: Inefficiency Estimates: Translog Model with Country Fixed Effects

\begin{tabular}{|c|c|c|c|c|c|c|}
\hline \multirow[b]{2}{*}{ Country } & \multicolumn{2}{|c|}{$\begin{array}{c}\text { Inefficiency } \\
\text { score }\end{array}$} & \multicolumn{4}{|c|}{$\begin{array}{c}\text { Efficiency } \\
\text { rankings }\end{array}$} \\
\hline & $\begin{array}{c}1880- \\
89 \\
\end{array}$ & $\begin{array}{c}1890- \\
99\end{array}$ & $\begin{array}{c}1900- \\
12\end{array}$ & $\begin{array}{c}1880- \\
89 \\
\end{array}$ & $\begin{array}{c}1890- \\
99\end{array}$ & $\begin{array}{c}1900- \\
12\end{array}$ \\
\hline US & 0.048 & 0.087 & 0.042 & 5 & 16 & 1 \\
\hline France & 0.066 & 0.054 & 0.044 & 7 & 12 & 2 \\
\hline Belgium & 0.062 & 0.062 & 0.047 & 6 & 15 & 3 \\
\hline Netherlands & 0.026 & 0.131 & 0.047 & 1 & 17 & 4 \\
\hline Russia & & 0.058 & 0.051 & & 14 & 5 \\
\hline Australia & & & 0.052 & & & 6 \\
\hline Britain & 0.045 & 0.052 & 0.055 & 4 & 10 & 7 \\
\hline India & 0.088 & 0.044 & 0.056 & 9 & 5 & 8 \\
\hline Norway & 0.07 & 0.055 & 0.057 & 8 & 13 & 9 \\
\hline Spain & 0.11 & 0.051 & 0.058 & 10 & 9 & 10 \\
\hline Argentina & & 0.048 & 0.059 & & 8 & 11 \\
\hline Germany & 0.042 & 0.054 & 0.059 & 3 & 11 & 12 \\
\hline Japan & & 0.045 & 0.065 & & 6 & 13 \\
\hline Switz. & & 0.039 & 0.065 & & 4 & 14 \\
\hline Austria & & 0.035 & 0.071 & & 3 & 15 \\
\hline Sweden & & 0.028 & 0.072 & & 2 & 16 \\
\hline Italy & & 0.027 & 0.073 & & 1 & 17 \\
\hline Canada & 0.042 & 0.045 & 0.078 & 2 & 7 & 18 \\
\hline Average & 0.06 & 0.054 & 0.058 & & & \\
\hline \multicolumn{4}{|c|}{ Correlation of inefficiency, 1880s, 1890s } & \multicolumn{3}{|c|}{-0.54} \\
\hline \multicolumn{4}{|c|}{ Correlation of inefficiency, 1890s, 1900s } & & & -0.68 \\
\hline
\end{tabular}

Sources: see text. 
Table 3: Summary of Inefficiency estimates under Alternative Specifications

\begin{tabular}{|c|c|c|c|c|}
\hline & $\begin{array}{c}\text { (1) } \\
\text { Translog }\end{array}$ & $\begin{array}{c}\text { (2) } \\
\text { Cobb-Doug. }\end{array}$ & $\begin{array}{c}\text { (3) } \\
\text { Cobb-Doug., } \\
\text { Homog. }\end{array}$ & $\begin{array}{c}(4) \\
\text { Translog, no } \\
\text { FE }\end{array}$ \\
\hline Average & 0.058 & 0.044 & 0.045 & 0.109 \\
\hline St. Dev. & 0.028 & 0.014 & 0.014 & 0.066 \\
\hline Min & 0.016 & 0.016 & 0.017 & 0.024 \\
\hline Max & 0.272 & 0.154 & 0.141 & 0.319 \\
\hline $\begin{array}{l}\text { Correlatior } \\
\text { model (1) }\end{array}$ & nslog & 0.86 & 0.84 & 0.73 \\
\hline
\end{tabular}

Sources: see text.

Notes: No FE means no country fixed effects. Homog means that the cost function is assumed to be homogenous of degree one in input prices. 
Table 4: Inefficiency Estimates: translog model without country fixed effects

\begin{tabular}{|c|c|c|c|c|c|c|}
\hline \multirow[b]{2}{*}{ Country } & \multicolumn{2}{|c|}{$\begin{array}{c}\text { Inefficiency } \\
\text { score }\end{array}$} & \multicolumn{4}{|c|}{$\begin{array}{c}\text { Efficiency } \\
\text { rankings }\end{array}$} \\
\hline & $\begin{array}{c}1880- \\
89 \\
\end{array}$ & $\begin{array}{c}1890- \\
99\end{array}$ & $\begin{array}{c}1900- \\
12\end{array}$ & $\begin{array}{c}1880- \\
89 \\
\end{array}$ & $\begin{array}{c}1890- \\
99\end{array}$ & $\begin{array}{c}1900- \\
12 \\
\end{array}$ \\
\hline France & 0.062 & 0.047 & 0.055 & 3 & 3 & 1 \\
\hline US & 0.146 & 0.143 & 0.062 & 9 & 15 & 2 \\
\hline Belgium & 0.107 & 0.083 & 0.066 & 6 & 8 & 3 \\
\hline Japan & & 0.124 & 0.086 & & 14 & 4 \\
\hline Russia & & 0.095 & 0.086 & & 10 & 5 \\
\hline Switz. & & 0.045 & 0.095 & & 2 & 6 \\
\hline Australia & & & 0.097 & & & 7 \\
\hline Norway & 0.113 & 0.110 & 0.099 & 7 & 13 & 8 \\
\hline Argentina & & 0.098 & 0.100 & & 11 & 9 \\
\hline Britain & 0.065 & 0.094 & 0.114 & 4 & 9 & 10 \\
\hline Sweden & & 0.053 & 0.116 & & 4 & 11 \\
\hline Germany & 0.162 & 0.159 & 0.142 & 10 & 16 & 12 \\
\hline India & 0.089 & 0.060 & 0.144 & 5 & 7 & 13 \\
\hline Spain & 0.143 & 0.106 & 0.147 & 8 & 12 & 14 \\
\hline Canada & 0.050 & 0.060 & 0.150 & 1 & 6 & 15 \\
\hline Netherland & 0.052 & 0.307 & 0.160 & 2 & 17 & 16 \\
\hline Austria & & 0.059 & 0.160 & & 5 & 17 \\
\hline Italy & & 0.042 & 0.217 & & 1 & 18 \\
\hline Average & 0.099 & 0.099 & 0.116 & & & \\
\hline \multicolumn{4}{|c|}{ Correlation of inefficiency, 1880s, 1890s } & \multicolumn{3}{|c|}{0.03} \\
\hline \multicolumn{4}{|c|}{ Correlation of inefficiency, 1890s, 1900s } & & & 0.07 \\
\hline
\end{tabular}

Sources: see text. 
Table 5: Parameter Estimates for the Translog and Cobb-Douglas Cost Functions

\begin{tabular}{|c|c|c|c|c|}
\hline Variable & \multicolumn{2}{|r|}{$\begin{array}{l}\text { Translog } \\
\text { (Stand. Err.) }\end{array}$} & \multicolumn{2}{|c|}{ Cobb-Douglas } \\
\hline LPM & 2.84 & $(0.85)^{* * *}$ & 0.33 & $(0.05) * * *$ \\
\hline LTM & -1.60 & $(0.84)^{*}$ & 0.40 & $(0.05)^{* * *}$ \\
\hline LRR & -0.49 & $(0.81)$ & 0.30 & $(0.09)^{* * *}$ \\
\hline LCO & -0.62 & $(0.80)$ & 0.18 & $(0.05)^{* * *}$ \\
\hline LWA & 1.22 & $(0.77)$ & 0.13 & $(0.04)^{* * *}$ \\
\hline LCA & -4.14 & $(1.30)^{* * *}$ & 0.35 & $(0.06)^{* * *}$ \\
\hline LPM*LPM & -0.10 & $(0.07)$ & & \\
\hline LRR*LRR & 0.04 & $(0.14)$ & & \\
\hline LTM*LTM & 0.27 & $(0.11)^{* * *}$ & & \\
\hline LPM*LTM & -0.11 & $(0.14)$ & & \\
\hline LPM*LRR & 0.14 & $(0.14)$ & & \\
\hline LTM*LRR & -0.30 & $(0.21)$ & & \\
\hline LCO*LWA & -0.03 & $(0.09)$ & & \\
\hline LCO*LCA & -0.03 & $(0.12)$ & & \\
\hline LCO*LCO & -0.02 & (0.09) & & \\
\hline LWA*LCA & -0.03 & $(0.12)$ & & \\
\hline LWA*LWA & 0.03 & $(0.06)$ & & \\
\hline LCA*LCA & 0.41 & $(0.12)^{* * *}$ & & \\
\hline LPM*LCO & -0.08 & $(0.04)^{*}$ & & \\
\hline LPM*LCA & 0.02 & $(0.06)$ & & \\
\hline LPM*LWA & 0.09 & $(0.05)^{*}$ & & \\
\hline LTM*LCO & 0.17 & $(0.04)^{* * *}$ & & \\
\hline LTM*LCA & -0.13 & $(0.06)^{* *}$ & & \\
\hline LTM*LWA & -0.06 & $(0.05)$ & & \\
\hline LRR*LCO & -0.1 & $(0.05)^{*}$ & & \\
\hline LRR*LCA & 0.24 & $(0.07) * * *$ & & \\
\hline LRR*LWA & -0.16 & $(0.05)^{* * *}$ & & \\
\hline YEAR & -1.00 & $(0.33)^{* * *}$ & -0.41 & $(0.36)$ \\
\hline YEAR*YEAR & 0.0002 & $(0.00008)^{* * *}$ & 0.0001 & (0.00009) \\
\hline Country fixed effects & & Yes & & Yes \\
\hline $\mathrm{N}$ & & 397 & & 397 \\
\hline Log-Likelihood & & 472 & & 409 \\
\hline Sigma v & & 0.058 & & 0.077 \\
\hline Sigma u & & 0.073 & & 0.075 \\
\hline
\end{tabular}

Notes: the dependent variable is the log of real total expenses. LPM, LTM, and LRR are the log of passenger miles, ton miles, and rail miles. LCO, LCA, and LWA are the log of real coal prices, the real user cost of capital, and real wages. Standard errors are in parentheses. $*, * *, * * *$ indicates significance at the $10 \%, 5 \%$, and $1 \%$ levels respectively. 
Table 6: State Ownership and Inefficiency: Cross-Country Variation

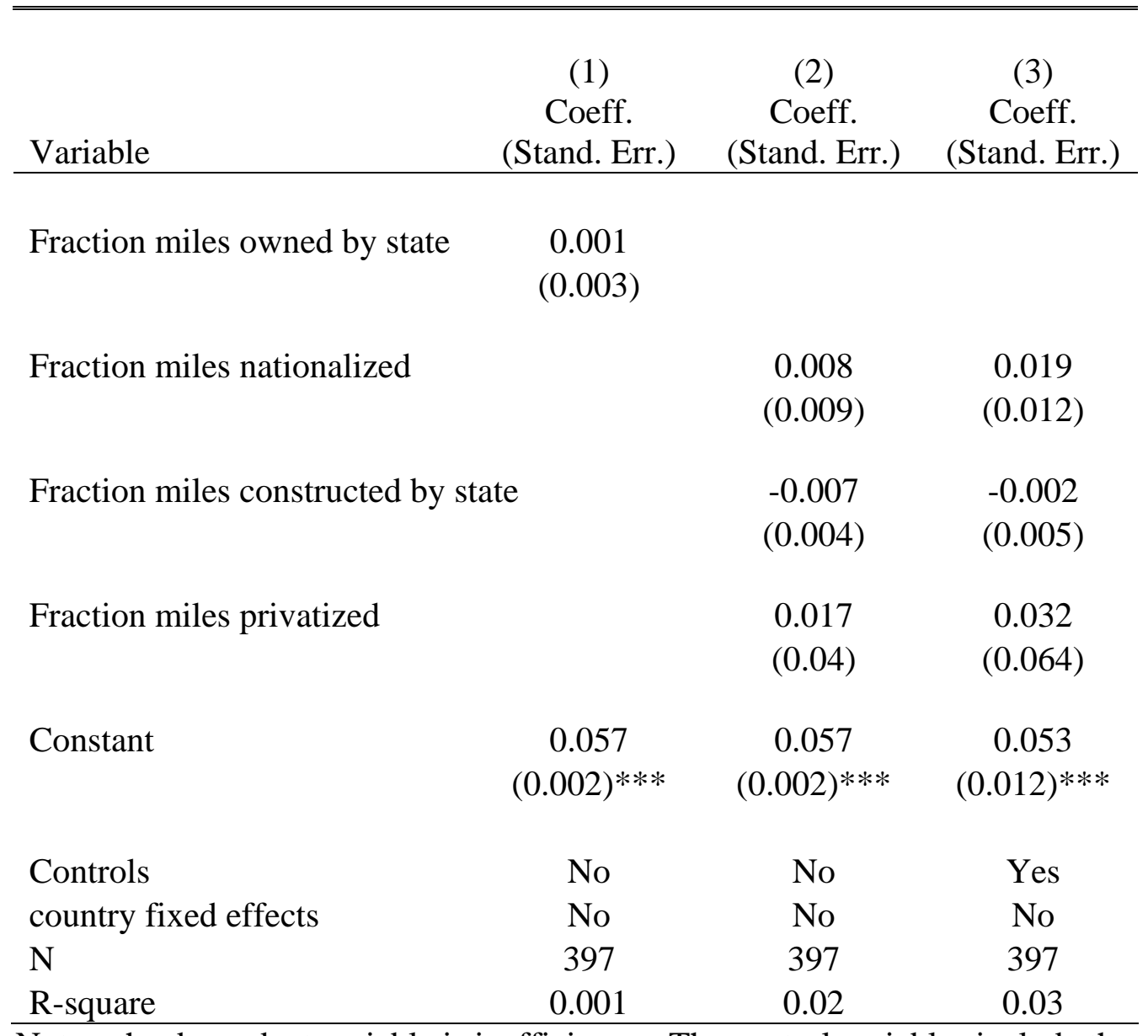

Notes: the dependent variable is inefficiency. The control variables include the average elevation, the standard deviation of elevation, the skew of elevation, the \% of land area within $100 \mathrm{~km}$ of the coast, the number of miles of navigable rivers and canals per square mile, the average age of the track, GDP per capita in the previous year, and the growth rate of GDP per capita. Robust standard errors are in parentheses. ****,*** indicates significance at the $10 \%, 5 \%$, and $1 \%$ levels respectively. 
Table 7: State Ownership and Inefficiency: Within-Country Variation

\begin{tabular}{|c|c|c|c|c|c|}
\hline Variable & $\begin{array}{c}(1) \\
\text { Coeff. } \\
\text { (Std. Er.) }\end{array}$ & $\begin{array}{c}(2) \\
\text { Coeff. } \\
\text { (Std. Er.) }\end{array}$ & $\begin{array}{c}\text { (3) } \\
\text { Coeff. } \\
\text { (Std. Er.) }\end{array}$ & $\begin{array}{c}(4) \\
\text { Coeff. } \\
\text { (Std. Er.) }\end{array}$ & $\begin{array}{c}(5) \\
\text { Coeff. } \\
\text { (Std. Er.) }\end{array}$ \\
\hline Fraction nationalized & $\begin{array}{c}0.109 \\
(0.022)^{* * *}\end{array}$ & $\begin{array}{c}0.104 \\
(0.035)^{* * *}\end{array}$ & $\begin{array}{c}0.109 \\
(0.020) * * *\end{array}$ & $\begin{array}{c}0.215 \\
(0.042)^{* * *}\end{array}$ & $\begin{array}{c}0.069 \\
(0.020)^{* *}\end{array}$ \\
\hline Fraction constructed by state & $\begin{array}{c}-0.544 \\
(0.121)^{* * *}\end{array}$ & $\begin{array}{c}-0.659 \\
(0.175) * * *\end{array}$ & $\begin{array}{c}-0.544 \\
(0.109) * * *\end{array}$ & $\begin{array}{c}-0.971 \\
(0.268) * * *\end{array}$ & $\begin{array}{l}-0.205 \\
(0.10)^{* *}\end{array}$ \\
\hline Fraction privatized & $\begin{array}{l}-0.138 \\
(0.247)\end{array}$ & $\begin{array}{c}-0.599 \\
(0.271)^{* *}\end{array}$ & $\begin{array}{l}-0.138 \\
(0.223)\end{array}$ & $\begin{array}{l}-0.122 \\
(0.584)\end{array}$ & $\begin{array}{l}-0.290 \\
(0.217)\end{array}$ \\
\hline Controls & Yes & Yes & Yes & Yes & Yes \\
\hline Country fixed effects & Yes & Yes & Yes & Yes & Yes \\
\hline Year fixed effects & Yes & Yes & Yes & Yes & Yes \\
\hline $\begin{array}{l}\text { Country specific time trends } \\
\text { Inefficiency estimate }\end{array}$ & $\begin{array}{c}\text { Yes } \\
\text { translog }\end{array}$ & $\begin{array}{c}\text { Yes } \\
\text { translog }\end{array}$ & $\begin{array}{c}\text { Yes } \\
\text { translog }\end{array}$ & $\begin{array}{l}\text { Yes } \\
\text { trans, no fe }\end{array}$ & $\begin{array}{c}\text { Yes } \\
\text { translog }\end{array}$ \\
\hline Tobit model & No & No & Yes & No & No \\
\hline Drop Netherlands: & No & No & No & No & Yes \\
\hline AR (1) disturbance & No & Yes & No & No & No \\
\hline $\mathrm{N}$ & 397 & 379 & 397 & 397 & 376 \\
\hline R-square & 0.35 & 0.21 & 0.43 & 0.43 & 0.34 \\
\hline
\end{tabular}

Notes: the dependent variable is inefficiency. The control variables include the average age of the track, GDP per capita in the previous year, and the growth rate of GDP per capita. Robust standard errors are in parentheses. *, **,*** indicates significance at the $10 \%, 5 \%$, and $1 \%$ levels respectively. 
Table 8: Inefficiency Prior to Nationalizations and Privatizations

\begin{tabular}{|c|c|c|c|}
\hline Variable & $\begin{array}{c}(1) \\
\text { Coeff. } \\
\text { (Stand. Err.) }\end{array}$ & $\begin{array}{c}(2) \\
\text { Coeff. } \\
\text { (Stand. Err.) }\end{array}$ & $\begin{array}{c}(3) \\
\text { Coeff. } \\
\text { (Stand. Err.) }\end{array}$ \\
\hline Fraction nationalized (1 year before) & $\begin{array}{c}0.072 \\
(0.023)^{* * *}\end{array}$ & & \\
\hline Fraction nationalized (2 years before) & & $\begin{array}{l}0.027 \\
(0.02)\end{array}$ & \\
\hline Fraction nationalized (3 years before) & & & $\begin{array}{l}-0.018 \\
(0.026)\end{array}$ \\
\hline Fraction privatized (1 year before) & $\begin{array}{l}0.269 \\
(0.27)\end{array}$ & & \\
\hline Fraction privatized (2 years before) & & $\begin{array}{c}0.675 \\
(0.246)^{* * *}\end{array}$ & \\
\hline Fraction privatized (3 years before) & & & $\begin{array}{c}0.832 \\
(0.3)^{* * * *}\end{array}$ \\
\hline Controls & Yes & Yes & Yes \\
\hline Country fixed effects & Yes & Yes & Yes \\
\hline Year fixed effects & Yes & Yes & Yes \\
\hline Country specific time trends & Yes & Yes & Yes \\
\hline Inefficiency estimate & translog & translog & translog \\
\hline $\mathrm{N}$ & 388 & 376 & 361 \\
\hline R-square & 0.29 & 0.28 & 0.3 \\
\hline
\end{tabular}

Notes: the dependent variable is inefficiency. The control variables include the average age of the track, GDP per capita in the previous year, and the growth rate of GDP per capita. Robust standard errors are in parentheses. *, **, *** indicates significance at the $10 \%, 5 \%$, and $1 \%$ levels respectively. 
Table 9: Trends in Inefficiency after Nationalizations

\begin{tabular}{|c|c|c|}
\hline Variable & $\begin{array}{c}(1) \\
\text { Coeff. } \\
\text { (Stand. Err.) }\end{array}$ & $\begin{array}{c}(2) \\
\text { Coeff. } \\
\text { (Stand. Err.) }\end{array}$ \\
\hline Fraction nationalized & $\begin{array}{c}24.26 \\
(8.262)^{* *}\end{array}$ & \\
\hline Year*Fraction nationalized & $\begin{array}{c}-0.012 \\
(0.004)^{* *}\end{array}$ & \\
\hline Fraction nationalized & & $\begin{array}{c}0.082 \\
(0.021)^{* * *}\end{array}$ \\
\hline Fraction nationalized (3 years later) & & $\begin{array}{c}-0.034 \\
(0.021)\end{array}$ \\
\hline Controls & Yes & Yes \\
\hline Country fixed effects & Yes & Yes \\
\hline Year fixed effects & Yes & Yes \\
\hline Country specific time trends & Yes & Yes \\
\hline Inefficiency estimate & translog & translog \\
\hline $\mathrm{N}$ & 397 & 397 \\
\hline R-square & 0.35 & 0.3 \\
\hline
\end{tabular}

Notes: the dependent variable is inefficiency. The control variables include the average age of the track, GDP per capita in the previous year, and the growth rate of GDP per capita. Robust standard errors are in parentheses. *, **, *** indicates significance at the $10 \%, 5 \%$, and $1 \%$ levels respectively. 
Table 10: Inefficiency Three Years before and after Large Increases in Private or State Railway Construction

\begin{tabular}{lc}
\hline \hline Variable & $\begin{array}{c}\text { Coeff. } \\
\text { (Stand. Err) }\end{array}$ \\
\hline Large private construction (All three years before) & 0.016 \\
& $(0.014)$ \\
Large private construction (Same year) & 0.048 \\
& $(0.030)$ \\
Large private construction (All three years after) & 0.030 \\
& $(0.013)^{* *}$ \\
Large state construction (All three years before) & 0.014 \\
& $(0.007)^{*}$ \\
Large state construction (Same year) & 0.023 \\
& $(0.007)^{* * *}$ \\
Large state construction (All three years after) & 0.008 \\
& $(0.006)$ \\
Controls & \\
Country fixed effects & Yes \\
Year fixed effects & Yes \\
Country specific time trends & Yes \\
Inefficiency estimate & Yes \\
R-square & Translog \\
\hline N & 397 \\
& 0.35 \\
\hline
\end{tabular}

Notes: the dependent variable is inefficiency. The control variables include the fraction of miles nationalized, the fraction of miles privatized, the average age of the track, GDP per capita in the previous year, and the growth rate of GDP per capita. Robust standard errors are in parentheses. *, **, *** indicates significance at the $10 \%, 5 \%$, and $1 \%$ levels respectively. 

Table 11: Counterfactual Inefficiency with no Nationalizations and no more than $25 \%$ State Railway Construction

\begin{tabular}{lcccc}
\hline \hline Country & $\begin{array}{c}(1) \\
\text { Inefficiency } \\
\text { with } \\
\text { observed } \\
\text { ownership }\end{array}$ & $\begin{array}{c}\text { Inefficiency } \\
\text { with no } \\
\text { nationalizations }\end{array}$ & $\begin{array}{c}\text { (3) } \\
\text { with no more } \\
\text { than 25\% state } \\
\text { construction }\end{array}$ & $\begin{array}{c}\text { (2) } \\
\text { nationalizations and } \\
\text { no more than 25\% } \\
\text { state ownership }\end{array}$ \\
\hline Switzerland & & & & \\
Austria & 0.065 & 0.028 & 0.065 & -0.037 \\
Japan & 0.071 & 0.033 & 0.083 & -0.026 \\
France & 0.065 & 0.027 & 0.086 & -0.017 \\
Argentina & 0.044 & 0.036 & 0.044 & -0.008 \\
Spain & 0.059 & 0.058 & 0.059 & -0.001 \\
US & 0.058 & 0.058 & 0.058 & 0.00 \\
Britain & 0.042 & 0.042 & 0.042 & 0.00 \\
Canada & 0.055 & 0.055 & 0.055 & 0.00 \\
Sweden & 0.078 & 0.078 & 0.078 & 0.00 \\
Italy & 0.072 & 0.071 & 0.082 & 0.009 \\
Belgium & 0.073 & 0.049 & 0.114 & 0.017 \\
Russia & 0.047 & 0.017 & 0.098 & 0.021 \\
Netherlands & 0.051 & 0.038 & 0.09 & 0.026 \\
Germany & 0.047 & 0.042 & 0.102 & 0.05 \\
India & 0.059 & 0.041 & 0.147 & 0.07 \\
Norway & 0.056 & 0.041 & 0.142 & 0.071 \\
Australia & 0.057 & 0.057 & 0.178 & 0.121 \\
Weighted & 0.052 & 0.051 & 0.177 & 0.124 \\
average & & & & \\
\hline & & & & 0.015 \\
\hline
\end{tabular}

Notes: The counterfactuals use the fraction nationalized and the fraction constructed by the state in table 1 and the coefficient estimates from Table 7 column 5 . The average at the bottom weighs each country's inefficiency by their size of rail network. 
Figures

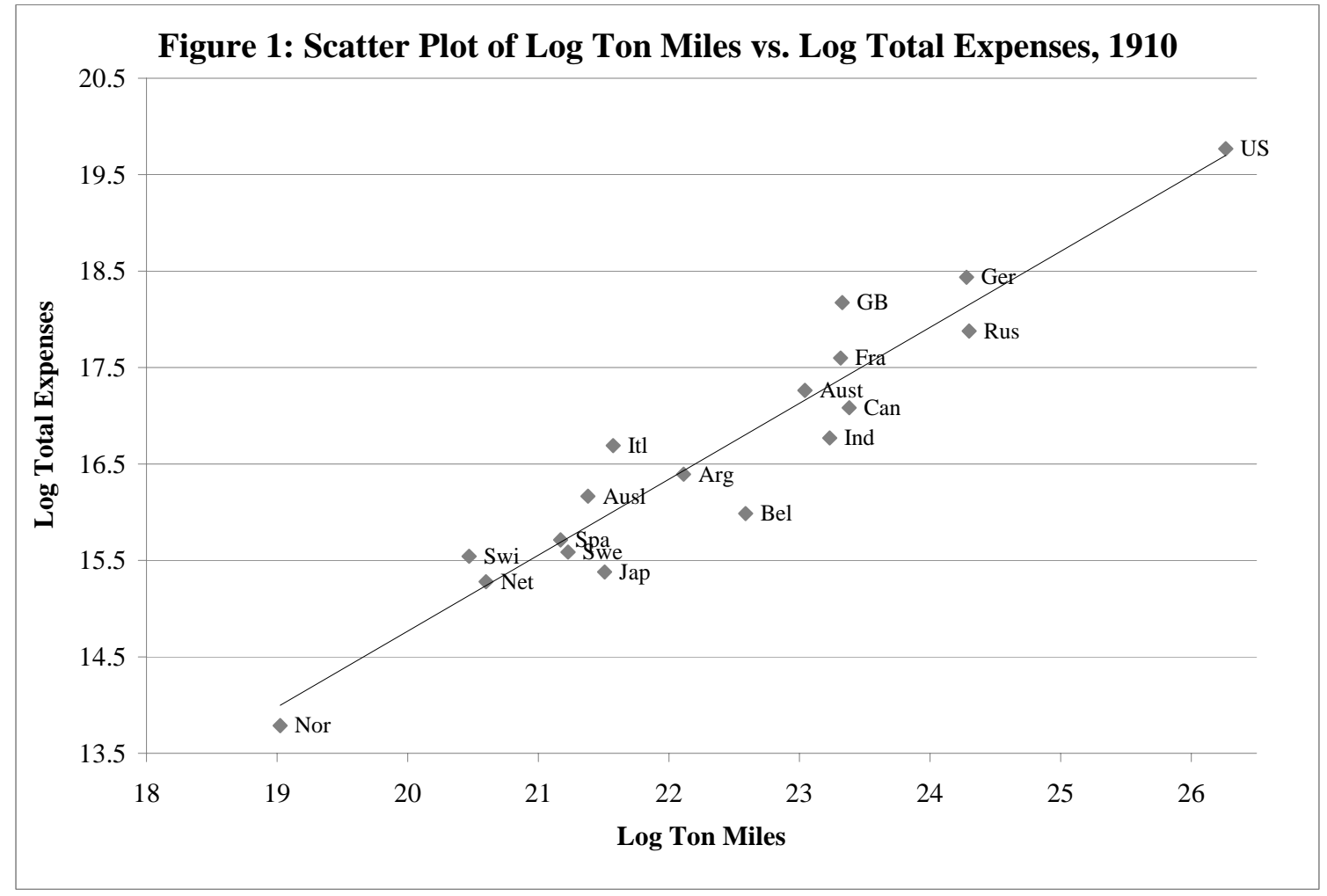




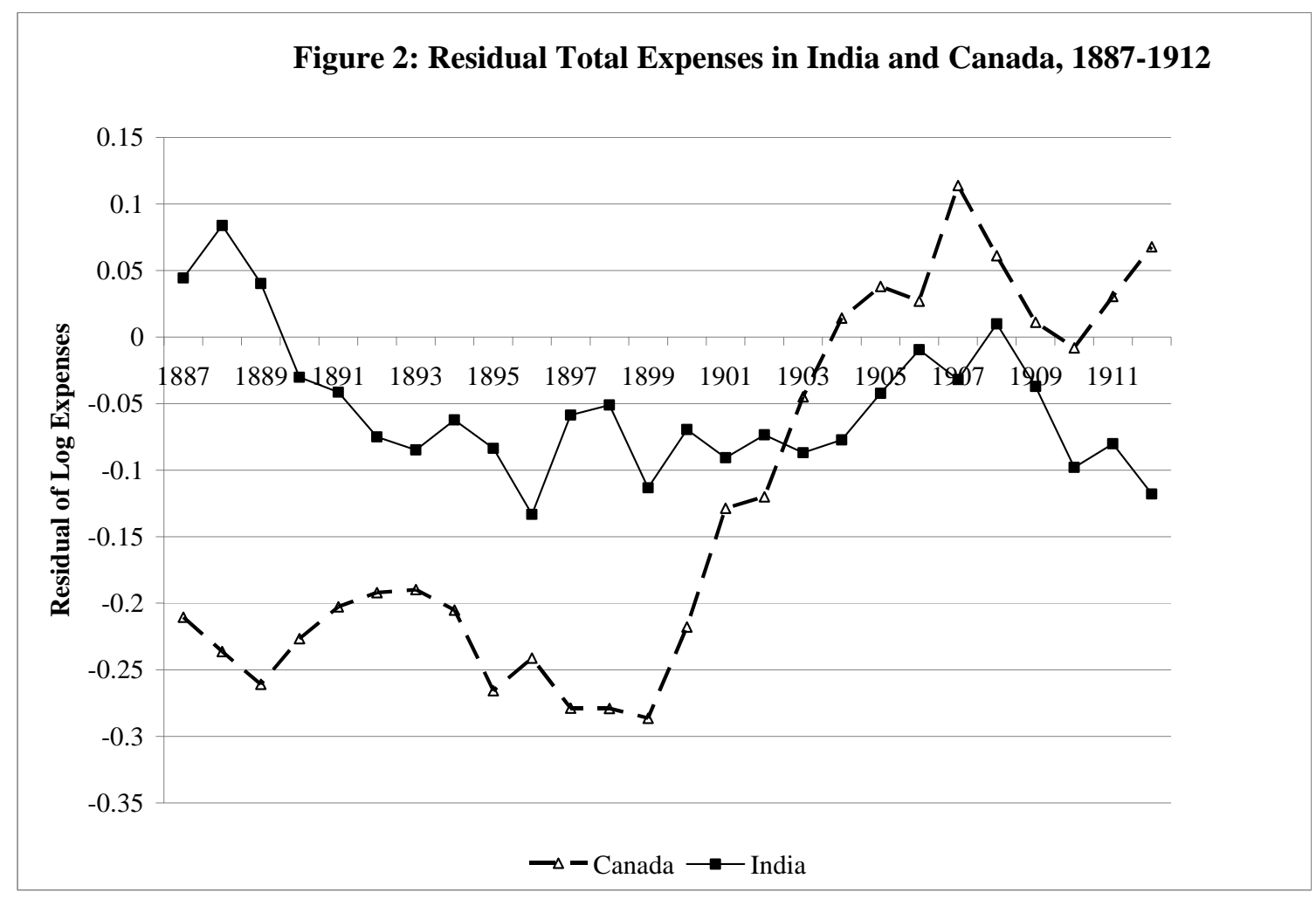




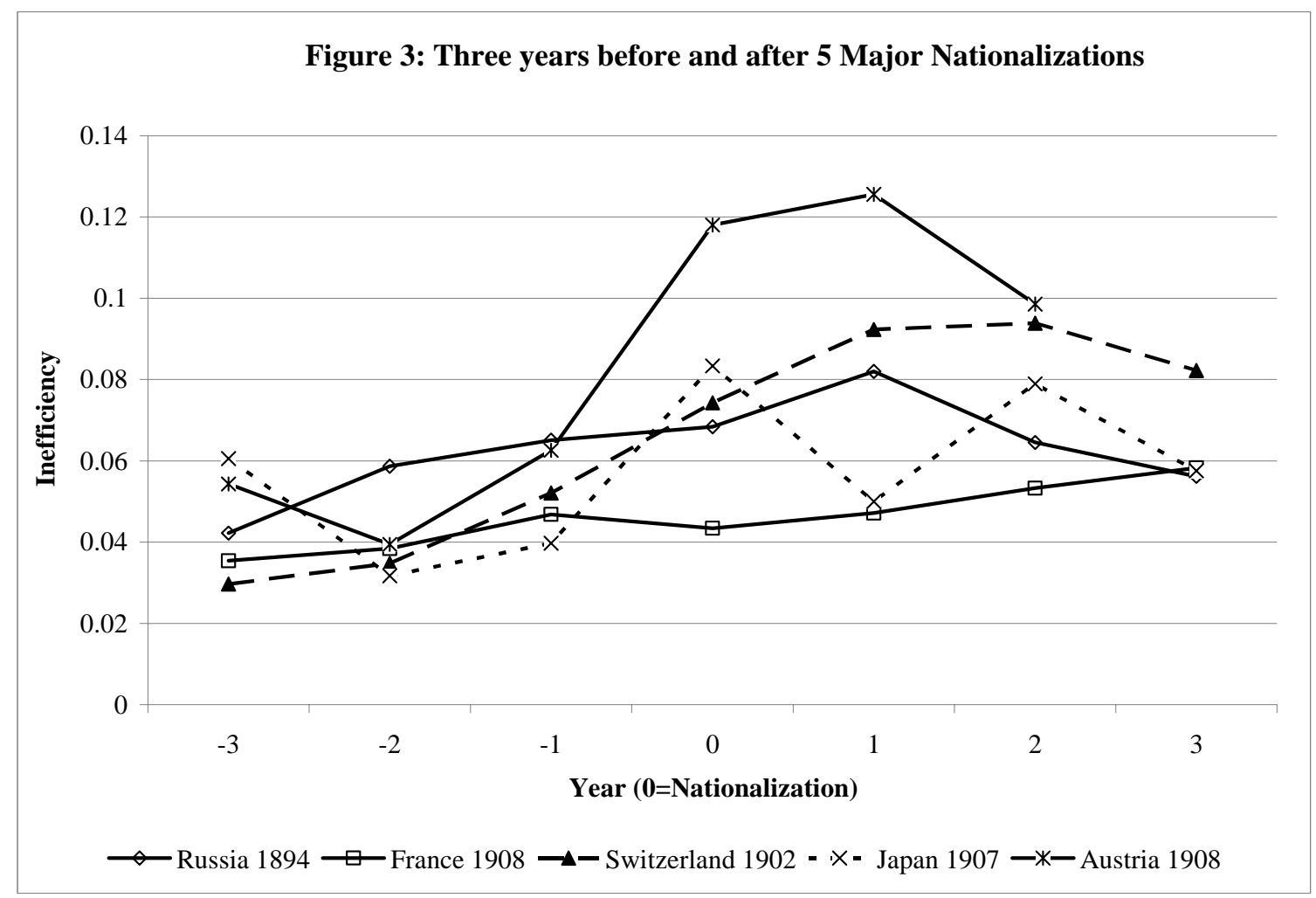

